\title{
Preserving the nutritional quality of crop plants under a changing climate: importance and strategies
}

\author{
José C. Soares • Carla S. Santos • Susana M. P. Carvalho • \\ Manuela M. Pintado • Marta W. Vasconcelos $(\mathbb{D}$
}

Received: 21 February 2019 / Accepted: 18 July 2019/Published online: 2 August 2019

(C) The Author(s) 2019

\begin{abstract}
Background Global climate is changing more rapidly than ever, threatening plant growth and productivity while exerting considerable direct and indirect effects on the quality and quantity of plant nutrients.

Scope This review focuses on the global impact of climate change on the nutritional value of plant foods. It showcases the existing evidence linking the effects of climate change factors on crop nutrition and the
\end{abstract}

Responsible Editor: Ismail Cakmak.

J. C. Soares · C. S. Santos · S. M. P. Carvalho ·

M. M. Pintado $\cdot$ M. W. Vasconcelos $(\bowtie)$

CBQF - Centro de Biotecnologia e Química Fina - Laboratório

Associado, Escola Superior de Biotecnologia, Universidade

Católica Portuguesa, Rua Diogo Botelho 1327, 4169-005 Porto,

Portugal

e-mail: mvasconcelos@porto.ucp.pt

J. C. Soares

e-mail: jsoares@porto.ucp.pt

C. S. Santos

e-mail: carla.sancho.santos@gmail.com

S. M. P. Carvalho

e-mail: susana.carvalho@fc.up.pt

M. M. Pintado

e-mail: mpintado@porto.ucp.pt

S. M. P. Carvalho

GreenUPorto - Research Centre on Sustainable Agrifood

Production \& DGAOT, Faculty of Sciences, University of Porto,

Campus de Vairão, Rua da Agra 747, 4485-646 Vairão, Portugal concentration of nutrients in edible plant parts. It focuses on the effect of elevated $\mathrm{CO}_{2}\left(\mathrm{eCO}_{2}\right)$, elevated temperature (eT), salinity, waterlogging and drought stresses, and what is known regarding their direct and indirect influence on nutrient availability. Furthermore, it provides possible strategies to preserve the nutritional composition of plant foods under changing climates.

Conclusions Climate change has an impact on the accumulation of minerals and protein in crop plants, with $\mathrm{eCO}_{2}$ being the underlying factor of most of the reported changes. The effects are clearly dependent on the type, intensity and duration of the imposed stress, plant genotype and developmental stage. Strong interactions (both positive and negative) can be found between individual climatic factors and soil availability of nitrogen $(\mathrm{N})$, potassium $(\mathrm{K})$, iron $(\mathrm{Fe})$ and phosphorous $(\mathrm{P})$. The development of future interventions to ensure that the world's population has access to plentiful, safe and nutritious food may need to rely on breeding for nutrients under the context of climate change, including legumes in cropping systems, better farm management practices and utilization of microbial inoculants that enhance nutrient availability.

Key words Climate change · Environmental factors . Elevated carbon dioxide $\cdot$ Minerals $\cdot$ Nutrient concentration

\section{Introduction}

Although the total global cultivated land area available for farmers has not changed significantly in the last 25 
years (O'Mara 2012), in many regions of the world crop yields have considerably increased. This has been due mostly to agricultural intensification practices and to targeted efforts in plant breeding aiming to increase yield. Nonetheless, human population is growing at a fast pace, with a $33 \%$ increase expected to happen in the next 30 years, reaching 9.6 billion by 2050 (Godfray et al. 2010; Manners and van Etten 2018; Ziervogel and Ericksen 2010). Consequently, global demands for food will continue to rise throughout this century. Crop yields and nutritional security are extremely dependent on the climatic conditions projected for the future, and consequently, most of the food produced for human consumption is under its menace (Burritt 2019). Despite efforts to increase global food availability, a key requirement for food and nutrition security, the global burden of malnutrition and micronutrient deficiencies remains alarming and closely linked to climate changes, particularly in low income communities (FAO 2017). Furthermore, climate changes are also responsible for changing the relationships between crops, pests, pathogens and weeds. It can also aggravate several trends, including decreasing pollinator insects, increasing water scarcity and ozone concentrations at ground level and reducing fishery levels. Therefore, it is imperative to know in more detail the impacts of climate change on food security and undernourishment and its potential implications for nutritional outcomes, reviewed by Myers et al. (2017) and Fanzo et al. (2018).

Climate change is a multifactorial stress (Gray and Brady 2016), and in the last decades, plants have experienced significant environmental fluctuations, which resulted in the global warming of the planet and in perturbations of the hydrological cycles. These environmental changes are likely to worsen, and their frequency of occurrence is likely to increase in the upcoming decades. Without mitigation and adaptation strategies, these changes will have a cumulative effect as time progresses (Fanzo et al. 2018). Therefore, in the coming decades climate change will present a major challenge to agriculture, natural ecosystems, and global economies, for producing enough and nutritious food, which has been reflected in a sustainable intensification of agricultural systems (Pretty et al. 2018).

Climate change has varying effects on plants responses at the level of molecular function, developmental processes, morphological traits, and basic physiological responses. It has been well documented that $\mathrm{eCO}_{2}$ increases plant growth and yield by enhancing photosynthesis, while oftentimes improving crop water-use efficiency (Dietterich et al. 2015; Grover et al. 2015; Guo et al. 2015; Han et al. 2015; Li et al. 2018b). However, improved plant growth at $\mathrm{eCO}_{2}$ contrasts with reducing grain quality responses, which are being recognized across a range of plant species (Dong et al. 2018b; Myers et al. 2014). This suggests that $\mathrm{eCO}_{2}$ changes the equilibrium among plant carbon metabolism and mineral uptake, and nutrient-use efficiency (Nakandalage and Seneweera 2018). Micronutrient deficiencies are a substantial public health problem, presenting serious health and nutritional consequences (Anandan et al. 2011). A great deal of emphasis has been given in recent decades to zinc ( $\mathrm{Zn})$ and iron (Fe) nutritional deficiencies, particularly in developing countries where a considerable proportion of people depend on grains and legumes as main food sources of these elements (Myers et al. 2014). Micronutrient limitation has also an impact on the susceptibility of plants to biotic and abiotic stresses. However, the response largely depends on plant genotype and each mineral element has complex interactions with several changing climate variables (Nakandalage and Seneweera 2018).

Elevated $\mathrm{CO}_{2}$ is closely related to increased demands for nutrients and water, resulting from increased plant growth. (Briat et al. 2015). Extending this knowledge to micronutrients, is also of particular importance because of their role in key biochemical pathways. In order to manipulate the most effective pathways for nutrient provision, it is important to propose predictive models that explain the future response mechanisms of plants to approaching worldwide environmental changes.

Herein we have focused on the current understanding of how climatic changes, with emphasis to $\mathrm{eCO}_{2}$, impact the nutritional quality of crop plants and their associated molecular and physiological response mechanisms. In addition, analysis of the interaction between $\mathrm{CO}_{2}$ enrichment and low soil nutrient availability will also be addressed. The final part of the review will be dedicated to report some of the strategies that can be used to preserve nutrient concentrations in future climates.

\section{An overview of climate changes as a global problem}

The climatic conditions in which our food-producing systems depend on have been shifting quickly and are 
projected to continue their current pathways unless significant interventions are made. The main cause of climate change is the release of anthropogenic greenhouse gases to the atmosphere, which have intensely increased since the pre-industrial era, determined largely by economic and population growth, and are now higher than ever. Constant release of greenhouse gases has led to atmospheric concentrations of $\mathrm{CO}_{2}$ at an unprecedented level and will cause further warming and exacerbate changes of the climate system, increasing the likelihood of severe and permanent impacts for people and ecosystems (Myers et al. 2017). These impacts, together with those of other anthropogenic drivers, have been the dominant cause of the observed global warming during the last decades. Thus, significant reductions in greenhouse gas emissions are required and here governmental authorities have a major role to play (Fanzo et al. 2018; IPCC 2014; Myers et al. 2017). Overall, 1.0 ${ }^{\circ} \mathrm{C}$ increase in global warming since the preindustrial era has been observed, and is expected to reach $1.5^{\circ} \mathrm{C}$ by 2050 if increases at the current rate are maintained (IPCC 2018). Moreover, it is expected that almost two billion people will be affected by almost complete water deficiency over the course of this century, and that close to $65 \%$ of the human population will be affected by circumstances of partial water insufficiency (Nezhadahmadi et al. 2013). Oscillations in the occurrence and intensity of normal precipitation patterns are also increasingly becoming a major global problem for agriculture, with a direct effect on the bioavailability of plant nutrients in the soil. The consequences may be a change in soil moisture that is a key factor in nutrient acquisition, as soil water provides the medium in which plants absorb and transport nutrients from, and that can affect nutrient allocation (Fischer et al. 2019).

Even if there will be yield improvements in some crops in different regions of the world, the global impact of climate change on agricultural products is expected to be negative, threatening global food security. Developing countries, which are already vulnerable to food shortage, are likely to be most seriously affected (Nelson et al. 2009). Consequently, our ability to ensure the required amounts of food and nutritional quality in the face of rapidly changing environmental conditions will be an important task for the near coming future.

\section{The importance of micronutrients in humans and in plants}

Micronutrients play a decisive role in maintaining health, because they have an essential role in cognitive growth and development, in reproductive functions and cell metabolism, and also in immune system responses of humans (Nakandalage and Seneweera 2018). Dietary deficiencies of micronutrients (i.e. hidden hunger) are considered as a global public health problem and it is already estimated to affect around two billion people worldwide (Haddad et al. 2015).

Accordingly, Fe limitation adversely disturbs growth, immune function and is the most common and widespread nutritional disorder in the world causing anemia (Murgia et al. 2012). Millions of people in developing countries are anemic comprising 50 and $40 \%$ of pregnant women and preschool children, respectively (Bouis and Saltzman 2017). Current studies show that Fedeficit in the first year of life is responsible for permanent effects on brain development, structure and function (Beard 2008). Furthermore, 0,2\% of deaths in children under 5 years of age can be attributed to Fe deficiency (Murgia et al. 2012).

Various biological functions have been atributed to $\mathrm{Zn}$, since it cooperates with many enzymes and other proteins and performs critical structural, functional and regulatory roles in the body (Krężel and Maret 2016). A large consumption of cereal-based foods is considered the main driver to $\mathrm{Zn}$ deficiency, since cereals have low concentration and bioavailability of $\mathrm{Zn}$ and cannot meet the human demand for Zn (Cakmak and Kutman 2018). Nowadays, wheat, rice and corn account for about $60 \%$ of the world's daily energy consumption, and bread wheat alone is the staple food for about $35 \%$ of the world's population (Poursarebani et al. 2014). In Asian countries with a high incidence of $\mathrm{Zn}$ and Fe-deficiencies, rice and wheat deliver over $70 \%$ of the daily calorie intake in rural areas (Cakmak et al. 2010; Cakmak and Kutman 2018).

The goal of biofortification is to solve some of these problems by increasing the concentration of micronutrients in the edible parts of crops and improving their bioavailability and absorption in the human body after digestion (Carvalho and Vasconcelos 2013; Ramzani et al. 2016; Vasconcelos et al. 2017). More than 20 million people in developing countries are consuming biofortified crop products. These include beans and pearl millet fortified with $\mathrm{Fe}$, maize, cassava and 
sweet potato fortified with provitamin A, and rice and wheat fortified with Zn (Bouis and Saltzman 2017). Vitamin A enriched rice (golden rice) produced by transgenic approaches has been made available since the beginning of this century (Wesseler and Zilberman 2014). However, this rice has not been introduced in any country, largely due to the lack of regulatory approval processes. These varieties have enormous nutritional potential and can be an effective economic solution reducing health costs.

Plants require 14 mineral nutrients to achieve for optimal development and growth (Marschner 2012). These elements are structural components of numerous macromolecules including nucleic acids, phospholipids, certain amino acids, and several coenzymes and play a central role in plant cellular metabolism (Grusak 2001). In addition, they are beneficial in chlorophyll biosynthesis, redox reactions, plasma membrane integrity and contribute to the osmotic potential of cells (Nakandalage and Seneweera 2018).

Micronutrient insufficiencies impact plant growth and yield by limiting the biosynthesis or expression of important mechanisms of energy capture and/or metabolism (Grusak 2001). Therefore, an increase in the vulnerability to abiotic stresses is usually encountered in plants that experienced micronutrient deficiency (Bencke-Malato et al. 2019; Hajiboland 2012; Jin et al. 2009). A comprehensive understanding of how these abiotic factors affect the regulatory mechanisms of micronutrients in plants is essential, in order to mitigate their negative effects on the nutritional quality of crop plants when grown under a changing climate.

\section{The influence of $\mathrm{eCO}_{2}$ on mineral accumulation}

The atmospheric $\mathrm{CO}_{2}$ levels have been progressing from the $280 \mathrm{ppm}$ preindustrial reference levels (Ainsworth and Long 2005; Myers et al. 2017) to current global levels which are now above $400 \mathrm{ppm}$ (IPCC 2018). Although the increasing concentration of atmospheric $\mathrm{CO}_{2}$ is the main driver of harmful anthropogenic climate changes, it can also improve crop performance by increasing rates of photosynthesis and water-use efficiency, particularly in $\mathrm{C} 3$ plants. The putative positive effect in agriculture is in fact denoted to as the " $\mathrm{CO}_{2}$ fertilization effect" (Ainsworth and Long 2005; Bowes 1993; Bunce 2015; Dietterich et al. 2015; Högy and
Fangmeier 2008; Loladze 2014; Long et al. 2004; Myers et al. 2017; Ziska and Bunce 2007). This effect has already been observed in crop plants and vegetables, including wheat (Dong et al. 2018c; Fernando et al. 2012a; Han et al. 2015; Högy and Fangmeier 2008), maize (Zong and Shangguan 2014), rice (Guo et al. 2015; Pang et al. 2006; Yang et al. 2007), barley (Haase et al. 2008; Mitterbauer et al. 2017), bean (Bunce 2008; Ma et al. 2017), soybean (Bunce 2015; Kumagai et al. 2015), cowpea (Dey et al. 2017), potato (Kumari and Agrawal 2014), lettuce, carrot, parsley (Dong et al. 2018b; Long et al. 2004; Mortensen 1994) and tomato (Jin et al. 2009) among others. However, longer treatments with $\mathrm{eCO}_{2}$ might lead to photosynthetic acclimation, due to increased soluble sugars leading to an imbalanced $\mathrm{C}: \mathrm{N}$ ratio, accelerated leaf senescence and/or limited growth rate (Ainsworth and Long 2005; Ainsworth et al. 2004; Kaplan et al. 2012; Ludewig and Sonnewald 2000).

Future models of climate change for the period of 2000-2100 predicted an overall decrease of the growing season length and crop transpiration, and increase in water-use efficiency, biomass production, and yields, but with considerable variation among crop models (Ahmed et al. 2017; Bassu et al. 2014).

Despite all the compelling evidence, there is still insufficient knowledge on the role of $\mathrm{eCO}_{2}$ in shifting the nutritional composition of crops and on the direct consequences to humans (Dong et al. 2018b; Duval et al. 2012; Fernando et al. 2012a; Guo et al. 2015; Högy and Fangmeier 2008; Jablonski et al. 2002; Li et al. 2018b; Loladze 2002; Myers et al. 2014). Therefore, Figure 1 gives an overview of the influence of climatic changes, particularly e $\mathrm{CO}_{2}$, on grain mineral concentrations and the mechanisms proposed as responsible for changing the plant mineral content.

Using a meta-analysis of FACE and non-FACE studies, Loladze (2014) described a significant reduction in overall mineral concentration $(\sim 8 \%)$ in $\mathrm{C} 3$ plants, including foliar and edible tissues. Precisely, $\mathrm{CO}_{2}$ enrichment lowered $\mathrm{Fe}, \mathrm{Zn}$, and $\mathrm{Cu}$ by $6.5-10 \%$, with $\mathrm{Mn}$ showing no significant changes. Through a detailed analysis of various plant groups, $\mathrm{eCO}_{2}$ reduced the mineral concentrations in crops $(-7.2 \%)$, wild (-9.7\%), herbaceous $(-7.5 \%)$, and woody $(-9.6 \%)$ plants combining data from foliar and edible tissues. Regarding different tissues, $\mathrm{eCO}_{2}$ decreased mineral concentrations in foliar $(-9.2 \%)$ and edible $(-6.4 \%)$ tissues, including grains $(-7.2 \%)$. The cereal specific decreases in grains 
were $-7.6,-7.2$ and $-6.9 \%$ for wheat, rice and barley, respectively (Loladze 2014).

Similar findings were obtained by Myers et al. (2014) in the edible portions of $\mathrm{C} 3$ grasses and legumes grown under field conditions at $\mathrm{eCO}_{2}$. A significant reduction in protein concentration in $\mathrm{C} 3$ grasses $(-6.3 \%$ in wheat grains and $-7.8 \%$ in rice grains), and no significant effects in soybeans or $\mathrm{C} 4$ crops were detected at $\mathrm{eCO}_{2}$. Authors also evaluated phytate concentration that affects mineral bioavailability. The phytate concentration declined significantly at $\mathrm{eCO}_{2}$ in wheat, which might partly counterbalance the nutritional impact of lower $\mathrm{Fe}$ and $\mathrm{Zn}$ concentrations in this crop caused by $\mathrm{eCO}_{2}$, and thus increasing their bioavailability (Myers et al. 2014). Decreases in the concentration of these important micronutrients in such significant food crops will put at risk the populations of the developing world. Iron concentration was also significantly reduced in soybean seeds at fresh edible stage (R6), while $\mathrm{Zn}$ and $\mathrm{Mn}$ concentrations varied among cultivars ( $\mathrm{Li}$ et al. $2018 b$ ). It was also found that $\mathrm{eCO}_{2}$ decreased $\mathrm{N}, \mathrm{Mg}$, $\mathrm{Fe}$, and $\mathrm{Zn}$ concentrations, and not affected $\mathrm{P}, \mathrm{K}, \mathrm{S}, \mathrm{Cu}$, and $\mathrm{Mn}$ concentrations in the edible part of vegetables (Dong et al. 2018b).

Nowadays, there is strong evidence that $\mathrm{Zn}$ deficiency is a significant global health problem affecting $17 \%$ of the world's population, and that increasing $\mathrm{CO}_{2}$ levels lower the concentration of $\mathrm{Zn}$ in significant food crops (Myers et al. 2017; Myers et al. 2015; Myers et al. 2014). In a meta-analysis with previously published data from FACE and growth chamber experiments, Myers et al. (2014) found a significant reduction in $\mathrm{Zn}$ concentration in wheat $(-9.1 \%)$, rice $(-3.1 \%)$, barley $(-13.6 \%)$, field peas $(-6.8 \%)$, and soybean $(-5.0 \%)$ grown at $\mathrm{eCO}_{2}$. Similarly, $\mathrm{eCO}_{2}$ decreased by $9.4 \%$ the $\mathrm{Zn}$ concentration in vegetables as described by Dong et al. (2018b). Thus, due to increased concentrations of atmospheric $\mathrm{CO}_{2}$ it was anticipated that 138 million of people will be placed at new risk of $\mathrm{Zn}$ deficiency by 2050 , and the most affected populations live in Africa and South Asia, with a particular incidence in India with 48 million people at risk (Myers et al. 2015).

The mechanisms responsible for the overall decline of plant mineral concentrations are not completely deciphered. Despite the "carbohydrate dilution" being a likely cause, it cannot elucidate all the mineral reductions because of the heterogenous response of each mineral tested for a given crop or for different species (Loladze 2002; Poorter et al. 1997). Moreover, decreases in transpiration rates reduces mass flow of nutrients, and shifting nutrient allocation driven by altered biochemical processes between tissues can both change nutrient uptake (McGrath and Lobell 2013). In addition, root architecture modification and downregulation of photosynthesis, reviewed in Taub and Wang (2008), and also inhibition of nitrate assimilation by decreased photorespiration (Bloom et al. 2002) have been proposed to elucidate the variations in mineral concentrations.

The $\mathrm{CO}_{2}$ concentration has also a direct effect on the bioavailability of nutrients in soils, and consequently affecting the number and diversity of existing microorganisms. A positive effect on soil nutrient bioavailability was described under $\mathrm{CO}_{2}$ enrichment conditions (Jablonski et al. 2002; Kimball et al. 2002). However, the increase in plant growth with $\mathrm{eCO}_{2}$ may have a disadvantage in terms of competition for micronutrient acquisition with microorganisms prevailing in the soil (Guo et al. 2015). Abbas et al. (2009) showed that $\mathrm{eCO}_{2}$ promoted increases in $\mathrm{P}, \mathrm{K}, \mathrm{Fe}, \mathrm{Mn}$ and $\mathrm{Zn}$ in the soil. Possibly, $\mathrm{eCO}_{2}$-induced changes in soil $\mathrm{pH}$ improves some exudation processes which affects the availability of nutrients in the soil. Similarly, it was described that $\mathrm{eCO}_{2}$ responses averaged across two $\mathrm{N}$ treatments increased the concentrations of $\mathrm{Ca}, \mathrm{Mg}, \mathrm{Fe}, \mathrm{Zn}$ and $\mathrm{Mn}$ at the soil surface by $15.6,9.5,23.4,138.2$ and $16.9 \%$, respectively (Guo et al. 2015). In another study, Jin et al. (2019) described the interaction of long-term $\mathrm{CO}_{2}$ conditions with different soil types (chromosol, vertosol, and calcarosol) on grain nutrient concentrations of wheat, field pea, and canola. At $\mathrm{eCO}_{2}$, the concentrations of N, P, and $\mathrm{Zn}$ decreased by 6,5 , and $10 \%$, respectively, regardless of soil, crop and year. In addition, the concentrations of $\mathrm{K}, \mathrm{Fe}, \mathrm{Mn}$ and $\mathrm{Cu}$ were not affected by $\mathrm{CO}_{2}$ enrichment in any crop grown in the soils tested.

Data concerning the impact of $\mathrm{CO}_{2}$ on other micronutrients, including selenium (Se), chromium $(\mathrm{Cr})$, and iodine (I), in food crops is still very limited. To our knowledge only two studies specified $\mathrm{CO}_{2}$ responses to $\mathrm{Se}$ and $\mathrm{Cr}$ accumulation (not significantly lowered by $\mathrm{eCO}_{2}$ ) in wheat (Högy et al. 2013, 2009), and none report data pertinent on I. Given that a billion people are I-deficient and I is the primary reason of preventable brain damage, cretinism, and lower IQ in children (Loladze 2014), so studies focusing on the impact of climate change on I content in food crops would be important. 


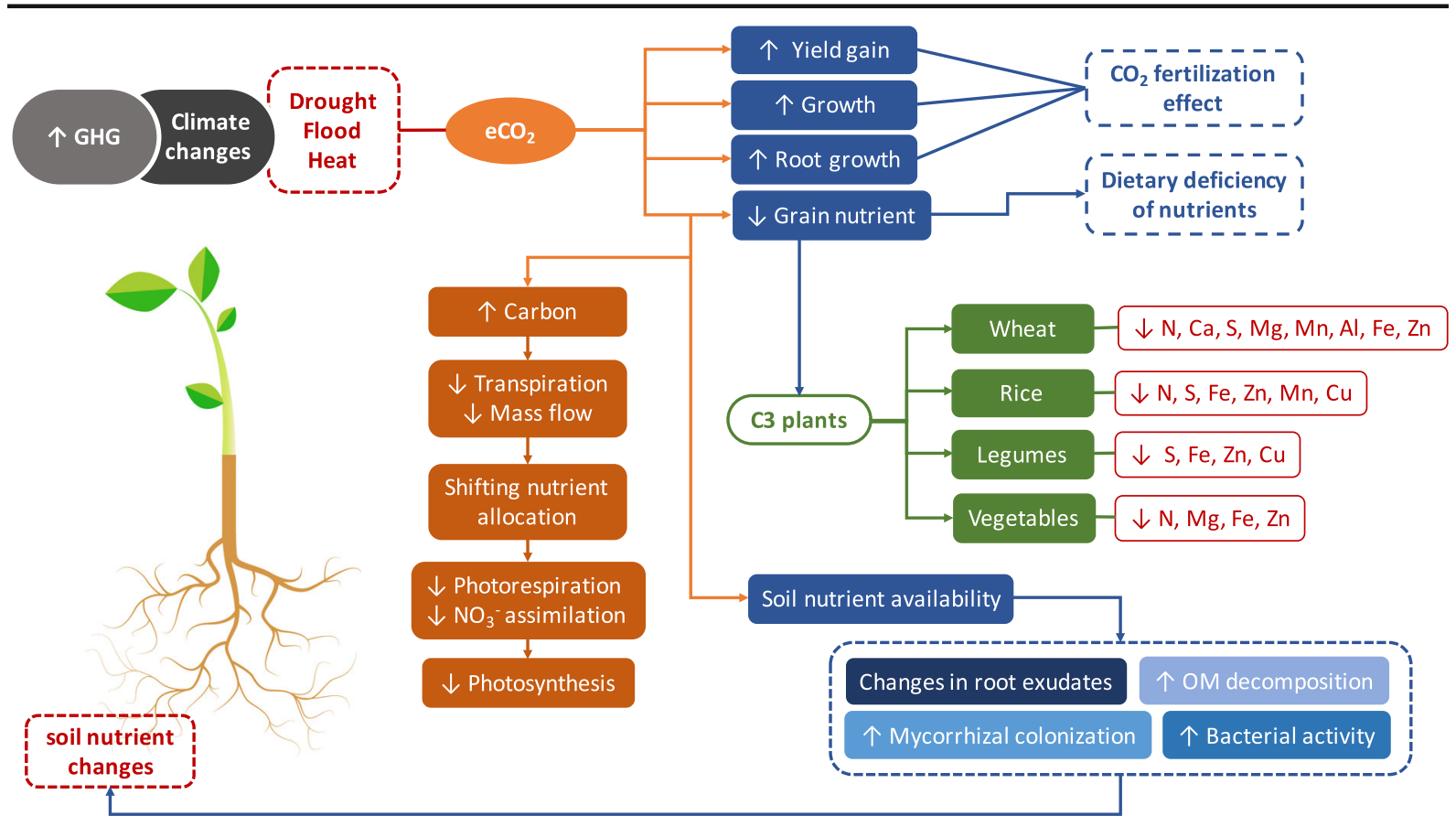

Fig. 1 Schematic illustration of the influence of climatic changes, driven by increased greenhouse gas (GHG) emissions, on grain mineral concentrations and their bioavailability in soil. The effects of $\mathrm{CO}_{2}$ on nutrient concentrations in edible tissues of $\mathrm{C} 3$ plants are reflected in FACE and non-FACE studies. The mechanisms proposed as responsible for changing the plant mineral concentration are: "carbohydrate dilution" in which there is an increase in carbon (C) assimilation relative to the mineral concentration, decrease in transpiration rates that reduces mass flow of nutrients, and shifting nutrient allocation by altered biochemical processes between

Furthermore, $\mathrm{eCO}_{2}$ may increase mycorrhizal colonization and protect plants against some stresses, having led to improved $\mathrm{P}$ nutrition, particularly on legumes (Jakobsen et al. 2016) and increased soil organic carbon decomposition (Cheng et al. 2012) facilitating the availability of some nutrients. In sum, a clear understanding of the nutrient-related processes that are impacted by climate change will increase our ability to predict responses for diverse crops and could benefit farmers in agronomic management to adapt crops to higher $\mathrm{CO}_{2}$.

One important final consideration under $\mathrm{eCO}_{2}$ is the overall effect of lower mineral concentrations while in promoting higher yields. For some situations it has been suggested that regardless of the decrease in grain nutrient concentrations at $\mathrm{eCO}_{2}$, overall availability of $\mathrm{Fe}$, $\mathrm{Zn}, \mathrm{Mn}, \mathrm{B}, \mathrm{Cu}, \mathrm{Ca}, \mathrm{N}$, and other macronutrients on a land area basis would actually be enhanced, due to grain yield increase at $\mathrm{eCO}_{2}$ conditions (Asif et al. 2017a; Fernando et al. 2012b). However, a trade-off effect must be considered because per serving size, the actual tissues can affect nutrient uptake. In addition, down-regulation of photosynthesis and increased photorespiration have been also expected to elucidate the variations in mineral concentrations. The $\mathrm{CO}_{2}$ concentration has also a direct effect on the bioavailability of nutrients in soils and, consequently, affecting the quantity of existing microorganisms. Possibly, due to changes in soil $\mathrm{pH}$, $\mathrm{eCO}_{2}$ improves the exudation processes affecting nutrient availability. Furthermore, the role of $\mathrm{eCO}_{2}$ increasing mycorrhizal colonization and organic matter (OM) decomposition in the soil, facilitating the availability of several nutrients

amount of minerals provided will still be lower, albeit the higher overall grain yields, which may not be sustainable in the long run due to $\mathrm{CO}_{2}$ acclimatization effects and faster depletion of mineral nutrients from the soil.

\section{The influence of $\mathrm{eCO}_{2}$ on protein accumulation}

Elevated $\mathrm{CO}_{2}$ has generally been shown to decrease the concentration of protein in grains of many crops species (Dong et al. 2018b; Högy and Fangmeier 2008; Medek et al. 2017; Myers et al. 2017, 2014), directly affecting human nutrition (Toreti et al. 2019). Consequently, millions of people may face protein deficiency since a great part of worldwide population depends on plant proteins (Medek et al. 2017).

Medek et al. (2017) confirmed that when grown under $\mathrm{eCO}_{2}$ conditions expected by the middle of this century (500-700 ppm), a lower protein concentration 
was found in $\mathrm{C} 3$ grains (wheat, rice and barley with -7.8, -7.6 , and $-14.1 \%$, respectively), potato $(-6.4 \%)$, vegetables $(-17.3 \%)$, and fruit $(-23.0 \%)$. The $\mathrm{eCO}_{2}$ was also responsible for a slight decrease in protein in legume species (-3.5\%), and no significant effects were found in oil crops and $\mathrm{C} 4$ plants. Accordingly, they anticipated a decrease in protein intake under $\mathrm{eCO}_{2}$ conditions by $>5 \%$ in 18 countries predominantly throughout Middle East and India. Moreover, it was highlighted that almost $12 \%$ of the world's population is currently at risk of protein deficiency. In the case of constant atmospheric $\mathrm{CO}_{2}$, they predict that globally, $15 \%$ (1.4 billion people) of world population would be at risk of protein deficiency by 2050 due mainly to demographic changes. However, with projections of $\mathrm{CO}_{2}$ levels above $500 \mathrm{ppm}$ by 2050 , it was expected that an additional 148.4 million people will be at risk of protein deficiency compared to the $2050 \mathrm{aCO}_{2}$ scenarios.

\section{The effects of other climate change factors on nutrient accumulation}

A permanent state of equilibrium in nutrient concentration is a decisive regulatory factor in maintaining nutritional quality and determining the ability of plants to withstand the impact of climate changes (Nakandalage and Seneweera 2018). Several studies have shown that several climatic changes may disturb the nutrient accumulation in major crops as demonstrated in Table 1. Therefore it is important to look at those studies dealing with the nutritional impact of $\mathrm{eCO}_{2}$ (Bunce 2015; Dietterich et al. 2015; Jin et al. 2015; Kumagai et al. 2015; Myers et al. 2014) or combined with water scarcity (Wu et al. 2004), soil mineral deficiency (Asif et al. 2018; Haase et al. 2008; Jin et al. 2009, 2014, 2015), elevated temperature (eT) (Bellaloui et al. 2016; Chaturvedi et al. 2017; Fernando et al. 2014), or salt stress (Chrysargyris et al. 2019; Petretto et al. 2019; Petropoulos et al. 2017; Scagel et al. 2019).

The effect of drought on nutrient accumulation was studied by Fischer et al. (2019) comparing food crops in two different regions of East Africa. Severe drought caused a decrease in nutrients, whereas mild drought actually caused an increase in nutrient concentrations. This shows that that the effects on nutrient accumulation are very depended not only on the type of climatic change but also on it intensity level. Water stress also resulted in significant changes in mineral concentrations of legumes (Hummel et al. 2018; Wijewardana et al. 2019) and vegetables (Sarker and Oba 2018). Contrastingly, limiting irrigation of grapevine in a glasshouse experiment did not result in significant differences in leaf micronutrient concentrations. However, when drought was accompanied by $\mathrm{Zn}$ deficiency, authors found that $\mathrm{Zn}$ pulverization was effective in increasing $\mathrm{Zn}, \mathrm{Fe}$ and $\mathrm{Mn}$ in leaf blades (Sabir and Sari 2019). Da Ge et al. (2010) reported a field study in order to assess the nutritional quality in maize grains at different soil moisture levels. Severe drought increased N, Ca, $\mathrm{Mg}, \mathrm{Cu}$ and $\mathrm{Zn}$ accumulation by $12 \%, 28 \%, 11 \%, 18 \%$, and $33 \%$, respectively, when compared to control. However, significant decreases in $\mathrm{P}$ and $\mathrm{K}$ concentration by $17 \%$ in both minerals were observed at severe drought. This suggests that the effects of drought on mineral concentration are nutrient specific.

The effects of combined water and heat stresses were studied by Velu et al. (2016) in 54 field-grown wheat varieties. Grain $\mathrm{Zn}$ concentration was higher under heat and drought stress conditions, whereas a lower increase of grain $\mathrm{Fe}$ was observed in water stress environments.

The interaction of drought stress with $\mathrm{eCO}_{2}$ on wheat was reported by Wu et al. (2004), and the authors found that $\mathrm{CO}_{2}$ enrichment alleviated the negative effects of drought stress, increasing water-use efficiency. However, grain quality was lower under $\mathrm{eCO}_{2}$ as reflected by consistent decreases in mineral nutrients (N, P, K and Zn). Parvin et al. (2019) observed a reduction in $\mathrm{Fe}, \mathrm{Zn}, \mathrm{P}$, and $\mathrm{S}$ concentrations in faba bean and lentil facing drought and $\mathrm{eCO}_{2}$ conditions. Asif et al. (2017a) reported interaction of $\mathrm{eCO}_{2}$, drought and soil $\mathrm{Zn}$ availability in wheat. It was found that $\mathrm{eCO}_{2}$ combined with low water and/or $\mathrm{Zn}$ availability resulted in reduced grain $\mathrm{Zn}$ and protein values. In addition, Asif et al. (2018) found that $\mathrm{eCO}_{2}$ partially improved the detrimental effect of soil $\mathrm{K}$ deficiency on wheat grain yield.

Climate changes are also characterized by soilrelated waterlogging complications due to natural factors or by human activities such as excessive irrigation and low drainage (Smethurst et al. 2005). Waterlogging leads to a decreased $\mathrm{O}_{2}$ availability in the soil with possible accumulation of phytotoxins, leaf chlorosis, stomatal closure (Wei et al. 2018) and restricted crop performance by decreasing soil mineral nutrient accessibility (Ashraf 2012). When Medicago sativa was exposed to flooding stress, a marked reduction in leaf and root nutrient accumulation $(\mathrm{B}, \mathrm{Cu}$ and $\mathrm{Zn}$ ) was 


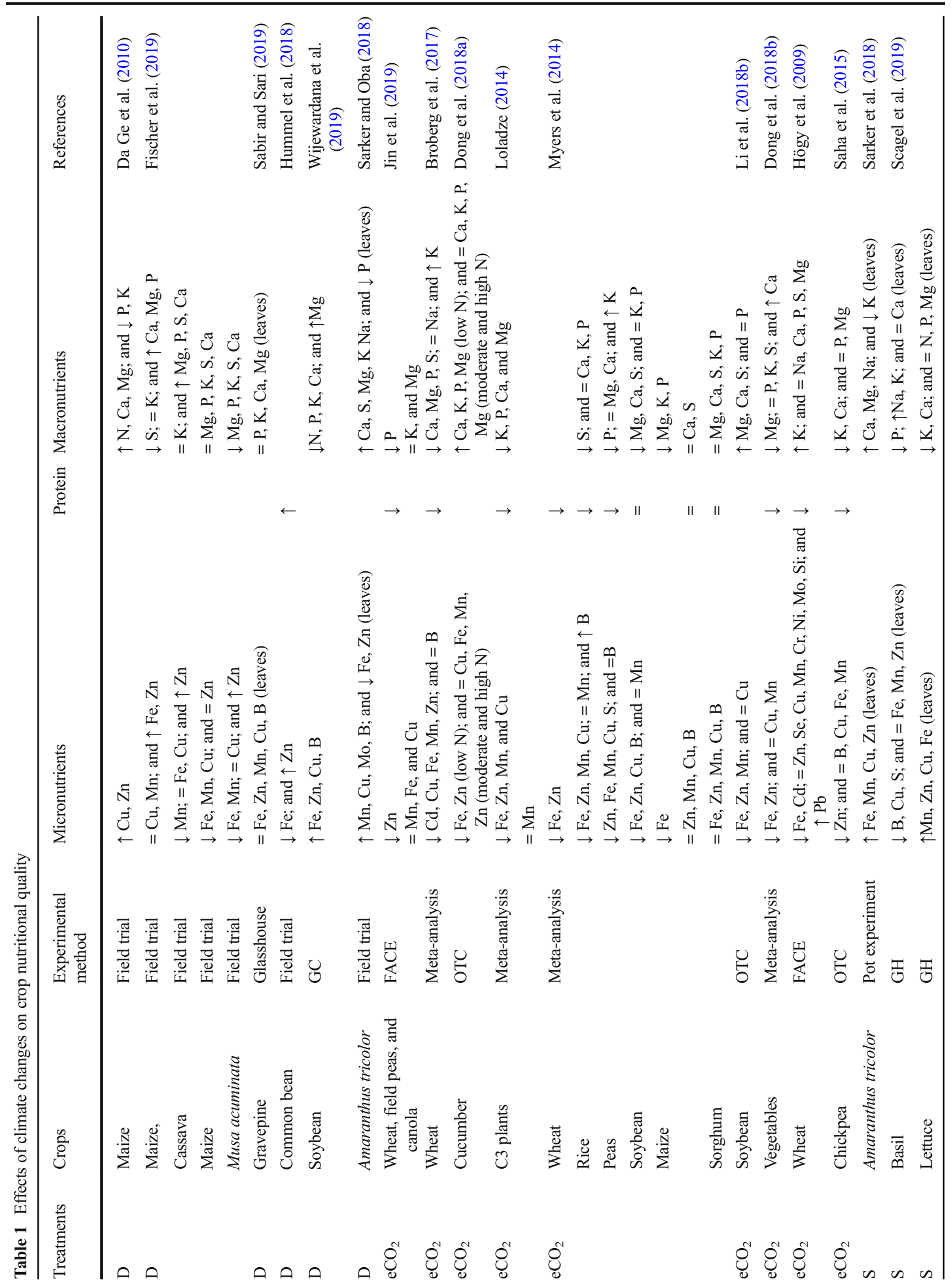




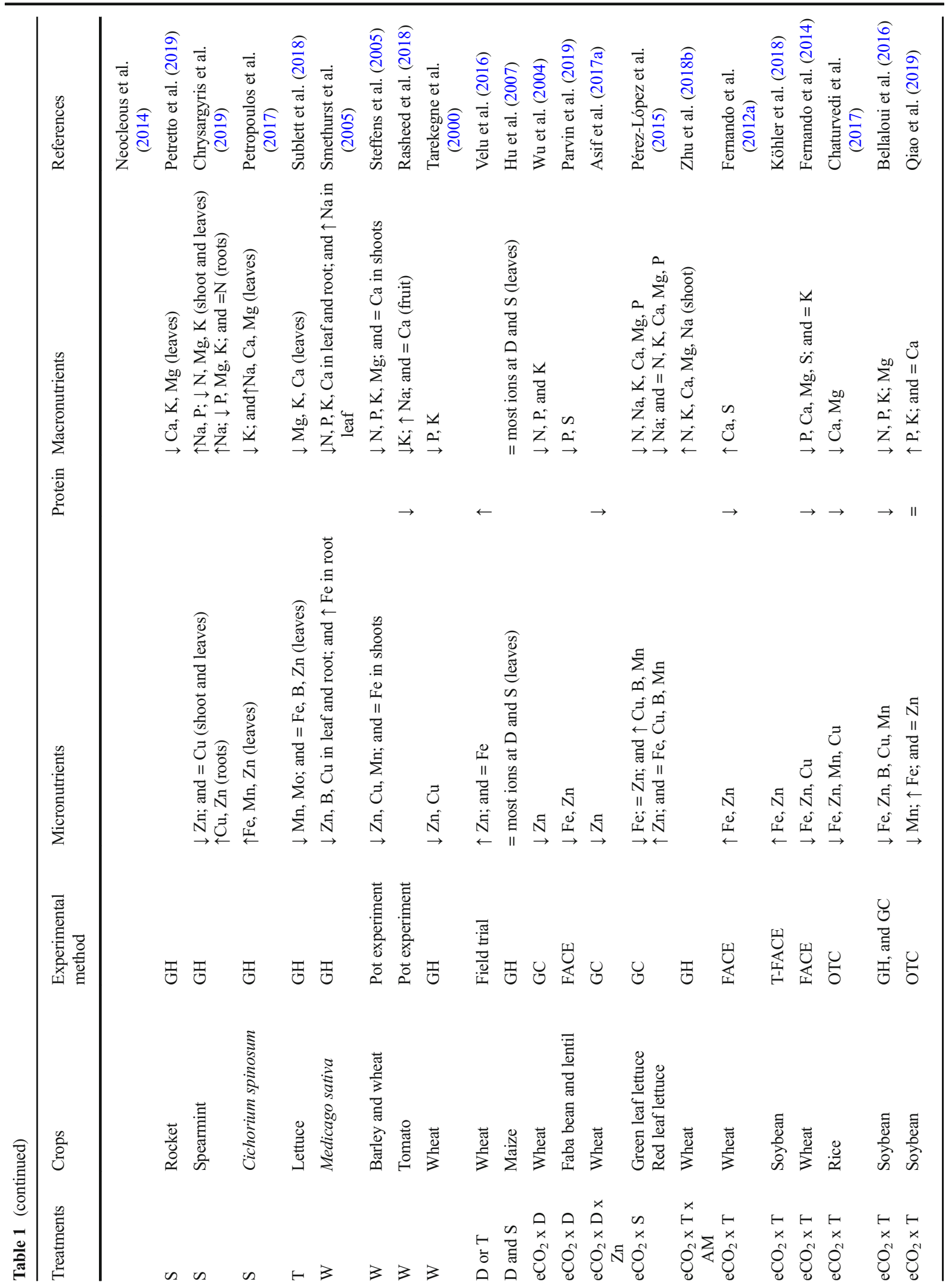


observed. Similar findings were obtained in barley and wheat shoots indicating that $\mathrm{Cu}, \mathrm{Zn}$, and $\mathrm{Mn}$ concentrations decreased significantly. The concentration of $\mathrm{Fe}$ was not affected (Steffens et al. 2005). Tarekegne et al. (2000) demonstrated that waterlogging-sensitive wheat genotypes appeared to accumulate less $\mathrm{Cu}$ and $\mathrm{Zn}$. Conversely, there were higher concentrations of $\mathrm{Fe}$ in waterlogged roots of stressed plants (Smethurst et al. 2005).To the best of our knowledge, there are no studies yet that have looked at the combined effect of waterlogging and $\mathrm{eCO}_{2}$ and their influence on plant nutritional quality, two conditions that are likely to interact in the future.

Sublett et al. (2018) studied the consequence of eT $\left(+8^{\circ} \mathrm{C}\right)$ on lettuce in a greenhouse experiment, and found a decrease in leaf $\mathrm{Mg}, \mathrm{K}, \mathrm{Ca} \mathrm{Mn}$ and Mo concentrations. When looking at temperature and $\mathrm{eCO}_{2}$, it was shown that the combination of both factors may restore soybean (Köhler et al. 2018) and wheat (Asif et al. 2019) seed $\mathrm{Fe}$ and $\mathrm{Zn}$ concentrations to levels obtained under ambient $\mathrm{CO}_{2}\left(\mathrm{aCO}_{2}\right)$. However, since there is a strong species and cultivar dependency on these responses, care must be taken to look at these aspects in detail. In a field study, Fernando et al. (2014) observed a cultivarbased response of wheat to $\mathrm{eCO}_{2}$ with high temperature. In addition, a decreasing trend in phytate concentration was also detected. Perceived genetic variability in terms of grain minerals could be easily combined into future wheat breeding programs to enable adaptation to climate changes.

In a FACE experiment, Fernando et al. (2012a) grew wheat at $\mathrm{aCO}_{2}$ and $\mathrm{eCO}_{2}$ in combination with two different sowing dates to mimic high temperature during grain filling. Grain mineral ( $\mathrm{Ca}, \mathrm{S}, \mathrm{Fe}$ and $\mathrm{Zn}$ ) concentrations were lower under $\mathrm{eCO}_{2}$ conditions. Most of the grain mineral concentrations were significantly increased at late sowing date, suggesting that at eT may counterbalance some of the negative effects of $\mathrm{eCO}_{2}$ on grain mineral concentration. Contrasting findings were obtained in rice (Chaturvedi et al. 2017) and soybean (Bellaloui et al. 2016). Qiao et al. (2019) also investigated the effects of eT in combination with $\mathrm{eCO}_{2}$ on grain quality of soybean and maize grown in open-top chambers in a Mollisol during five growing seasons. Elevated temperature with $\mathrm{eCO}_{2}$ increased $\mathrm{K}$, and $\mathrm{Fe}$, whereas $\mathrm{Ca}$ and $\mathrm{Zn}$ concentrations were not statistically affected in both species. In addition, $\mathrm{P}$ and Mn concentrations were species dependent. The metabolic responses to $\mathrm{eT}\left(+10^{\circ} \mathrm{C}\right)$ under $\mathrm{eCO}_{2}$ were studied in tall 
fescue, a cool-season grass species. Plants showed a significant increase in the quantity of several organic acids, amino acids, and carbohydrates involved in photosynthesis, respiration, and protein metabolism. Consequently, it was determined that $\mathrm{eCO}_{2}$ could play a role in mitigation of heat stress damage (Yu et al. 2012). In rice, $\mathrm{eCO}_{2}$ at ambient temperature increased plant growth and led to increased seed yield. However, increasing temperature to $35^{\circ} \mathrm{C}$ or higher, exceeded the beneficial effects of $\mathrm{eCO}_{2}$ (Madan et al. 2012). The combination of eCO2 with eT has a variable effect on growth and photosynthesis, and is dependent on the range of temperature increase, but in general $\mathrm{eCO}_{2}$ reduced the negative impact of eT (Köhler et al. 2018; Qiao et al. 2019; Yu et al. 2012). This was confirmed in soybean and maize over five-year growing seasons in open top chambers (Qiao et al. 2019).

Soil salinity is a global problem for agricultural production, since almost $20 \%$ percent of the total arable land is deteriorated due to high salinity (Neocleous et al. 2014; Scagel et al. 2019). There are several studies assessing the effects of salinity on mineral concentration and nutritional quality on crops plants. These studies have been conducted mainly in vegetables (Chrysargyris et al. 2019; Neocleous et al. 2014; Petretto et al. 2019; Petropoulos et al. 2017; Scagel et al. 2019), with contrasting responses among different species (Table 1). Pérez-López et al. (2015) studied the effect of salt stress combined with $\mathrm{eCO}_{2}$ on the nutritional quality of two differently pigmented lettuce cultivars. The red cultivar was the best adapted to $\mathrm{eCO}_{2}$ because it better adjusted mineral uptake. They concluded that $\mathrm{eCO}_{2}$ alone or in combination with short environmental salt stress allows increasing the concentration of some minerals. $\mathrm{Hu}$ et al. (2007) induced short-term events of drought and salinity stress in maize and found that both stresses frequently originate lower nutrient accessibility in soil and low nutrient translocation in plants. However, reduction in the micronutrient concentrations in the grain was not detected.

It is now clear that one of the main nutrient groups being impacted by climate change are minerals, and one of the biggest challenges of today's agricultural sector is to increase crop productivity and maintain nutritional quality of grains in a sustainable way, despite the influences of climate change.

\section{Plant molecular and physiological responses to climate change factors}

Plant responses underlying nutritional losses due to climate change involve complex biological processes that include several physiological and metabolic mechanisms. How plants respond to these changes has been the subject of several studies (Ahuja et al. 2010; Dong et al. 2018b; Feng et al. 2014; Hashiguchi et al. 2010; Hatfield and Walthall 2014; Hummel et al. 2018; Nakandalage and Seneweera 2018; Nakashima et al. 2009; Newton et al. 2011; Saeed et al. 2012). In this section, we will discuss the current understanding of how plants respond to environmental stresses at the molecular and physiological level.

Vicente et al. (2018) reported the impacts of $\mathrm{eCO}_{2}$, temperature and $\mathrm{N}$ supply on the regulation of $\mathrm{C}$ and $\mathrm{N}$ metabolism in durum wheat. They found a coordination between $\mathrm{C}$ and $\mathrm{N}$ metabolisms at biochemical and transcriptional levels. Genes from $\mathrm{N}$ uptake and assimilation were co-expressed with genes belonging to the respiratory pathway, highlighting the coordination between the synthesis of organic $\mathrm{N}$ compounds and $\mathrm{C}$ metabolism. Moreover, included in this coordination were Rubisco and nitrate reductase activities. The combination of eT with $\mathrm{eCO}_{2}$ in soybean seed composition and transcript levels was also studied. The impact of temperature on seed composition and transcripts level was pronounced, particularly on Gm8, similar to ADR12, and on Gm19, similar to $\beta$-glucosidase, but there was no effect of $\mathrm{CO}_{2}$ concentration (Thomas et al. 2003). Additionally, a network analysis of relationships between biochemical parameters of soybean grains showed that interaction of $\mathrm{eCO}_{2}$ with eT significantly affect carbohydrate and lipid metabolisms (Palacios et al. 2019). However, as previously shown, in some cases, a positive interaction of $\mathrm{eCO}_{2}$ and eT may also occur (PérezJiménez et al. 2019; Vu and Allen 2009) particularly in biomass accumulation. Parameters such as leaf area, leaf dry weight and stem dry weight of sugarcane was increased under $\mathrm{eCO}_{2}$ or eT $\left(4.5^{\circ} \mathrm{C}\right)$. Such changes were even greater under the combined treatment of $\mathrm{eCO}_{2}$ and eT (Vu and Allen 2009).

As previously mentioned, the effects of $\mathrm{CO}_{2}$ enrichment on plants depend on soil water availability, and plants can greatly benefit from $\mathrm{eCO}_{2}$ in terms of biomass accumulation when enough water is provided (Wu et al. 2004; Zhao et al. 2006). Most studies confirm that $\mathrm{CO}_{2}$ enrichment tends to mitigate drought negative 
effects (Asif et al. 2017a; Bencke-Malato et al. 2019; Li et al. 2018a; Sicher and Barnaby 2012; Wang et al. 2018a; Yuhui et al. 2017) by improving plant water relations, reducing stomatal opening and transpiration, increasing photosynthesis, shortening crop growth period and increasing the antioxidant activity (Kumar et al. 2019). In rice, both treatments have no interactive effects on maximal quantum yield of PSII photochemistry, intrinsic efficiency of PSII and non-photochemical quenching. However, in soybean $\mathrm{eCO}_{2}$ reduced the negative effects of drought on effective quantum yield of PSII photochemistry and photochemical quenching coefficient (Wang et al. 2018a), showing that these responses are very species specific.

Drought and temperature induce oxidative damage in legumes and grasses. These effects may be mitigated by $\mathrm{eCO}_{2}$, more extensively in legumes, due to lowered photorespiration and reduction of NADPH oxidase activity. The increased antioxidant activity (flavonoids and tocopherols) possibly also contributes to the stress mitigation effect of $\mathrm{CO}_{2}$ enrichment (Abdelgawad et al. 2015). In another study looking at drought and $\mathrm{eCO}_{2}$, in maize, transcript levels of 14 genes encoding stress responsive proteins were monitored. All the transcripts were induced by drought except for $r b c S 1$, but this response was delayed by $\mathrm{CO}_{2}$ enrichment. Accordingly, $\mathrm{eCO}_{2}$ had a larger impact on maize responses to drought at the beginning rather than at the end stages of water stress (Sicher and Barnaby 2012), showing that the importance of the developmental stage on understanding these responses.

Li et al. (2018a) used a metabolomics approach to search for metabolites that were affected by $\mathrm{eCO}_{2}$ under drought stress in cucumber leaves. The results showed that under severe drought, $\mathrm{eCO}_{2}$ changed several metabolic pathways related to the metabolism of several amino acids and carbohydrate synthesis. In $\mathrm{eCO}_{2}$ plants accumulated more amino acids and carbohydrates, 1,2,3-trihydroxybenzene, pyrocatechol, glutamate, and $\mathrm{L}$-gulonolactone, for better tolerating drought stress. The improved root growth and mitigation of drought stress under $\mathrm{eCO}_{2}$ was also described by Burgess and Huang (2014). This could be associated with alteration in proteins involving nitrogen metabolism (glutamine synthetase), energy metabolism involving respiration (glyceraldehyde-3-phosphate dehydrogenase), and stress defense by increasing antioxidant metabolism (ascorbate peroxidase, superoxide dismutase, and catalase) and chaperone protection (HSP81-1).
Elevated $\mathrm{CO}_{2}$ and salinity, individually, seem to affect plant growth in opposite directions (Shahbaz and Ashraf 2013; Zaghdoud et al. 2016). Salt stress, in contrast to $\mathrm{eCO}_{2}$, is generally considered a negative driver for growth of crop plants, especially in arid and semi-arid zones (Zaghdoud et al. 2016). This was confirmed by Kazemi et al. (2018) in rice who described a significant cultivar-dependent response to $\mathrm{eCO}_{2}$ under different salinity concentrations. Both treatments, besides influencing secondary metabolism, can disturb the oxidative system while acting in different directions, with salinity provoking, and $\mathrm{eCO}_{2}$ alleviating, oxidative stress (Sgherri et al. 2017). Similarly, Kanani et al. (2010) investigated the effects of $\mathrm{eCO}_{2}$ with salinity on the transcriptional and metabolic responses of Arabidopsis thaliana. The observed metabolic differences suggest that $\mathrm{eCO}_{2}$ mitigates the metabolic effect of the salinity stress. However, a strong similarity was observed between the transcriptional responses to salt stress and combination of $\mathrm{eCO}_{2}$ with salt stress (Kanani et al. 2010). In lettuce, both treatments originated a higher concentration of phenolic compounds, in particular luteolin, and increased plant growth and nutritional quality comparing to salinity alone (Pérez-López et al. 2015). Broccoli treated with $90 \mathrm{mM} \mathrm{NaCl}$ and $\mathrm{eCO}_{2}$, had higher photosynthetic rate and water-use efficiency. These factors led to greater leaf area and biomass as well as to increased abundance of aquaporins in roots and leaves at $\mathrm{eCO}_{2}$, in comparison with $\mathrm{aCO}_{2}$ (Zaghdoud et al. 2013). In Bermuda grass, salinity stress induced a reduction in leaf water content, leaf photosynthetic rate, transpiration rate, stomatal conductance, and cellular membrane stability. Elevated $\mathrm{CO}_{2}$ mitigated the depression of those physiological parameters and promoted osmotic adjustment by accumulation of soluble sugars, proline, and glycine betaine under salinity stress (Yu et al. 2015).

Recently, a transcriptome combined with proteome study discovered key factors involved in alfalfa waterlogging-based responses. The authors identified genes-related to beta-amylase, ethylene response factor, calcineurin B-like interacting protein kinases, glutathione peroxidase, and glutathione-S-transferase with key roles in conferring alfalfa tolerance to waterlogging (Zeng et al. 2019). Elevated $\mathrm{CO}_{2}$ is also capable of reducing the negative effects of waterlogging as demonstrated in several species (Arenque et al. 2014; Lenssen et al. 1995; Pérez-Jiménez et al. 2017a, b; Shimono et al. 2012). Hence, waterlogging affected 
sweet cherry cultivars severely by reducing photosynthesis, stomatal conductance, transpiration, chlorophyll fluorescence and plant growth (Pérez-Jiménez et al. 2017a). Proline accumulation, to cope with oxidative damage, was also observed. Nevertheless, increasing $\mathrm{CO}_{2}$ concentration not only mitigated all these effects but also induced the production of soluble sugars and starch in the leaf (Pérez-Jiménez et al. 2017b). In woody plants, Lawson et al. (2017) found species-specific effects of $\mathrm{CO}_{2}$ concentration and waterlogging on plant growth, gas exchange, and functional traits, and no evidence for an overall effect of $\mathrm{eCO}_{2}$ in mediating plant responses to flooding. In pea and soybean, an association among tolerance to hypoxia (induced by flooding), the rate of reactive oxygen species production, and antioxidant enzyme activities was recognized. The environment with the higher $\mathrm{CO}_{2}$ concentration induced higher changes in the processes of reactive oxygen species accumulation and activities of lipoxygenase and antioxidant enzymes (Ershova et al. 2011).

In fact, the observed nutritional impacts due to climate change may also be linked to alterations in below ground interactions between plants and microorganisms. In flooded soils, rice plants responded more positively to the $\mathrm{CO}_{2}$ enrichment than the non-flooded soil. The results advocate that in tropical rice soils, $\mathrm{eCO}_{2}$ amplified $\mathrm{C}$ accumulation in the soil, which possibly stimulates growth of $\mathrm{N}$ fixing bacteria and thereby higher available N (Das et al. 2011). In wheat, a mutualistic symbiosis with arbuscular mycorrhizal increased carbohydrate and nutrient accumulation in plants exposed to $\mathrm{eCO}_{2}$ and salinity ( $\mathrm{Zhu}$ et al. 2018b). Thus, looking at the impact of climate change on below ground traits and linking these with processes of nutrient absorption and accumulation seems like a promising line of research for future studies. However, care must be taken at factoring in issues of low nutrient availability in the soil.

\section{Effects of $\mathrm{eCO}_{2}$ under low soil nutrient availability}

The availability of nutrients in the soil has a significant influence on the effects of $\mathrm{eCO}_{2}$ on plant nutritional quality. Usually, a low nutrient availability limits the $\mathrm{eCO}_{2}$ effect on plant photosynthetic rates, possibly resulting in less carbon available for producing secondary compounds (Dong et al. 2018b).
Under different levels of $\mathrm{N}$ supply, rice grain quality was not significantly affected by $\mathrm{eCO}_{2}$ in a FACE experiment (Yang et al. 2007). In addition, soil mineral bioavailability was enhanced by $\mathrm{eCO}_{2}$ in rice, both under high and low $\mathrm{N}$ supply. It was also demonstrated that $\mathrm{eCO}_{2}$ can favor the translocation of $\mathrm{Ca}, \mathrm{Mg}, \mathrm{Fe}, \mathrm{Zn}$ and $\mathrm{Mn}$ from the soil to the stem, leaf and panicle but decreased in grains (Guo et al. 2015). However, Haase et al. (2007) observed symptoms of $\mathrm{N}$ deficiency in common bean plants grown under $\mathrm{eCO}_{2}$ conditions. The authors suggest that this is possibly due to improved root exudation and a related stimulation of soil microbial growth causing enhanced plantmicrobial N competition. Asif et al. (2019) studied the interactive effects of predicted climate $\left(\mathrm{eCO}_{2}\right.$ and $+3^{\circ} \mathrm{C}$ ) and $\mathrm{N}$ and $\mathrm{Zn}$ supply on growth and yield of wheat plants. In both predicted climate and environment conditions, low supply of $\mathrm{N}$, significantly decreased straw and grain yield by affecting the number of spikes per plant and number of grains per spike.

The bioavailability of soil $\mathrm{P}$ to plants is often restricted due to their strong bonding in insoluble forms. However, plants generally develop potential adaptive mechanisms that enhance $\mathrm{P}$ uptake in plants under $\mathrm{P}$ starvation (Wissuwa et al. 2005). The photosynthetic inhibition caused by low P supply could be overcome by $\mathrm{eCO}_{2}$. Furthermore, photosynthetic down-regulation at $\mathrm{eCO}_{2}$ could be reversed by increasing $\mathrm{P}$ supply. This might be due to the availability of sufficient $P$ to support increased protein degradation and metabolic rates at $\mathrm{eCO}_{2}$, enhancement in Rubisco activation, ribulose-1,5 bisphosphate regeneration and global energy demands (Pandey et al. 2015). In addition, in cotton plants grown under P stress, an apparent limitation of $\mathrm{CO}_{2}$ diffusion across stomata and mesophyll was observed (Singh et al. 2013; Singh and Reddy 2014). Under limited P supply, $\mathrm{eCO}_{2}$ increased acid phosphatase activity, responsible for hydrolyzing insoluble $\mathrm{P}$ in the soil (Barrett et al. 1998; Niu et al. 2012). However, there are some studies reporting no increase in root phosphatase activity in response to $\mathrm{P}$ shortage caused by $\mathrm{eCO}_{2}$ (Norisada et al. 2006; Wasaki et al. 2003). Elevated $\mathrm{CO}_{2}$ with low $\mathrm{P}$ supply also results in increased root dry matter. Changes in the processes at the soil level including root morphology, exudation and mycorrhizal association are also influenced by $\mathrm{eCO}_{2}$ and $\mathrm{P}$ bioavailability (Pandey et al. 2015; Pang et al. 2018; Watts-Williams et al. 2019). 
Potassium is an important plant nutrient with a significant role in key physiological processes as described by Cakmak (2005). Yilmaz et al. (2017a) determined growth performance and antioxidant response in wheat plants grown at different $\mathrm{K}$ levels under different $\mathrm{CO}_{2}$ conditions. In low and deficient $\mathrm{K}$ plants, biomass was either not affected or even decreased by $\mathrm{eCO}_{2}$. Additionally, limitation of $\mathrm{K}$ induced oxidative stress, and $\mathrm{eCO}_{2}$ had no significant impact on the antioxidant system. Similarly, K deficiency clearly limited the effects of $\mathrm{eCO}_{2}$ induced biomass enhancement in both well-watered and drought stressed plants (Asif et al. 2017b). Under severe K limitation, several photosynthesis-related parameters were down regulated in common bean. However, $\mathrm{eCO}_{2}$ also stimulated carbon assimilation and $\mathrm{K}$ utilization efficiency when $\mathrm{K}$ deficiency was not severe (Singh and Reddy 2018).

Magnesium has a determinant role in biosynthesis of proteins, nucleic acids, ATP and chlorophyll by activating several enzymatic reactions involving carboxylases, polymerases, kinases, and phosphatases (Cakmak and Kirkby 2008). To our knowledge, there is only one published study dealing with interaction of $\mathrm{eCO}_{2}$ with low and adequate $\mathrm{Mg}$ treatments on durum wheat growth and nutrient composition. Low $\mathrm{Mg}$ plants responded to $\mathrm{eCO}_{2}$ by decreasing biomass, particularly in roots and $\mathrm{eCO}_{2}$ increased photosynthesis in adequate$\mathrm{Mg}$ plants, but not in low Mg plants. Leaf carbohydrate concentration was increased 2-fold by low $\mathrm{Mg}$ at aCO and 3-fold at $\mathrm{eCO}_{2}$, (Yilmaz et al. 2017b) suggesting that low $\mathrm{Mg}$ and $\mathrm{eCO}_{2}$ decreased carbohydrate transport from source to sink tissues.

In plants, $\mathrm{Zn}$ is associated with the activity of several enzymes, it has a structural role in cell metabolism and is implicated in DNA replication and transcription as an intrinsic component of $\mathrm{Zn}$ metalloproteins. Zinc deficiency is related with the suspension of photosynthetic activity since this mineral is required for the activity of carbonic anhydrase and because the availability of substrate for carboxylation is limited under $\mathrm{Zn}$ limitation (Broadley et al. 2012). Asif et al. (2017a) noticed that $\mathrm{eCO}_{2}$ increased wheat grain yield, number of spikes per plant and straw yield under sufficient and low $\mathrm{Zn}$ conditions. Furthermore, Zn efficiency (yielding ability under low $\mathrm{Zn}$ supply) was positively affected by $\mathrm{eCO}_{2}$ which also reduced grain $\mathrm{Zn}$ concentration.

Iron metabolism in crop plants as well as its influence on productivity are already well referenced in the literature (Briat et al. 2015; İncensu et al. 2015; Kobayashi and Nishizawa 2012; Li et al. 2008; López-Millán et al. 2009; Zocchi et al. 2007). Therefore, similar to $\mathrm{eCO}_{2}$ it is very likely that restricted Fe availability will impact on nutritional quality of foods, which we will consume in the future (Vasconcelos et al. 2014; Vasconcelos et al. 2017). So far, researchers have been assessing these issues independently and studies linking these two important aspects are scarce.

Expanding this knowledge to $\mathrm{Fe}$ is of particular interest because of its major role in the photosynthetic process and because its bioavailability to plants is often limited, particularly in calcareous soils, which represent $30 \%$ of cultivated soils (Briat et al. 2015; Robin et al. 2008). Several papers described organic acid concentration increases, mainly citrate and malate, in xylem sap, leaf apoplastic fluid and whole leaves of plants with $\mathrm{Fe}$ deficiency (Abadía et al. 2002; Larbi et al. 2010; LópezMillán et al. 2009; López-Millán et al. 2000). Further changes include shifts in the redox state of the cytoplasm, increases in the activity of phosphoenolpyruvate carboxylase and in several enzymes of the Krebs cycle and of the glycolytic pathway. For a detailed description of the metabolic changes induced in Fe-stressed plants, see Zocchi (2006) and Zocchi et al. (2007). Transcriptomic (Thimm et al. 2001), proteomic and metabolomic studies (Brumbarova et al. 2008; Li et al. 2008; Rellán-Álvarez et al. 2010; Rodríguez-Celma et al. 2016) in Fe-deficient plants have also reported increases in root transcript and protein abundances, respectively, of enzymes-related to the glycolysis, Krebs cycle, anaerobic respiration, stress-related and metabolism-related proteins, among others. In barley, $\mathrm{CO}_{2}$ enrichment increased biomass production in $\mathrm{Fe}-$ deficient and Fe-sufficient plants, both in hydroponics and soil experiments. Higher Fe accumulation in shoots $(+52 \%)$ of barley grown in soil without $\mathrm{Fe}$ supply under $\mathrm{eCO}_{2}$ conditions were achieved, demonstrating an improved Fe-use efficiency (Haase et al. 2008). Similar findings were obtained in tomato (Jin et al. 2009). Plant biomass and root-to-shoot ratio were greater under $\mathrm{eCO}_{2}$ conditions than plants grown in $\mathrm{aCO}_{2}$. Root and shoot $\mathrm{Fe}$ concentration significantly increased in $\mathrm{Fe}$ deficient plants under $\mathrm{eCO}_{2}$ attenuating the symptoms of chlorosis, and were not changed in the Fe-sufficient plants. Authors also suggested some involvement of nitric oxide in enhancing Fe deficiency responses (increased ferric chelate reductase activity, and expression of FRO1, IRT1, and FER genes in roots) when Fe limitation and $\mathrm{eCO}_{2}$ occured together. The nutrient 
supply and, accordingly, the nutrient status of plants should be a critical issue defining growth responses to the $\mathrm{eCO}_{2}$. It was observed that $\mathrm{eCO}_{2}$ treatments significantly increased the $\mathrm{Fe}$ concentrations in tomato leaves and alleviated the Fe deficiency induced chlorosis when grown in Fe-limited medium (Jin et al. 2009).

The data concerning the interaction of $\mathrm{eCO}_{2}$ and $\mathrm{Fe}$ deficiency are very scarce in the literature despite the importance of this micronutrient in plant metabolism. Thus, a better understanding of the interaction of these two factors and how they affect metabolic pathways in plants is required.

\section{Strategies to preserve the nutritional content in future climates}

As described in the previous sections, the combination of different climate change factors will impact precipitation patterns, plant physiology and the functioning of the ecosystem, ultimately resulting in environmental constraints which limit nutrient uptake and accumulation. Several practices are under way to mitigate and/or adapt to climate change consequences (Fig. 2), but the high variability in research regarding their real environmental impact impair the definition of a strategy to be successfully implemented in supply chains (Parajuli et al. 2018).

The practices associated to agricultural production are a main target for climate change mitigation. Agricultural planning and farmers' sensitization might contribute not only for climate change mitigation, but also to climate change adaptation. For example, one strategy frequently mentioned in adaptation frameworks is the relocation and protection of farms, namely by moving crop production to promote food security from extreme weather events (Prior et al. 2018).

With climate change, soil quality declines, mostly because soil microbial communities are deeply affected, negatively impacting the degradation of organic pollutants (Ai et al. 2018) and soil organic matter (Chen et al. 2016) or nitrogen fixation (Lobo et al. 2018). In order to prevent nutritional losses of crops farmers must work towards yield optimization and smart fertilization decisions. Currently, fertilization decision support systems can be accessed via online platforms. These are based on algorithms that include experimental data on soil nutrition and crop nutritional requirements and provide farmers fertilizer recommendations and professional fertilization information specific to their farming conditions (Elia and Conversa 2015; He et al. 2011). This allows utilizing a controlled amount of fertilizer, achieving optimum yields and increasing nutrient-use efficiency. Nowadays, the development of technologies for noninvasive nutritional estimation in plants is growing. With these, crop monitoring and diagnosis are improved and targeted, once again facilitating the optimum fertilizer application for desirable production outcomes (Zheng et al. 2018). Examples of these techniques include hyperspectral imaging, successfully utilized in discriminating $\mathrm{N}$ nutritional levels in tea plants (Wang et al. 2018b), as well as N, P, K, S, Cu, Zn, Fe and Mn levels in maize and soybean plants (Pandey et al. 2017); unmanned aerial vehicle based multispectral imagery applied in the estimation of plant nitrogen concentration and management of $\mathrm{N}$ fertilizer application in rice (Zheng et al. 2018) and in wheat (Zhu et al. 2018a); and reflectance spectroscopy through which authors were able to characterize Fe deficiency symptoms in grapevine and prospect the possibility of detecting in field Fe deficiency conditions (Rustioni et al. 2017).

Additionally, sustainable alternatives to synthetic fertilizers which may sustain plant nutrition in a changing climate include plant growth-promoting bacteria (PGPB) inoculants, which can be used as biological fertilizers (Olanrewaju et al. 2017). These are associated with many mechanisms that improve not only plants' health, but also soil conditions, such as, phosphate solubilisation, nitrogen fixation, siderophore and phytohormone production, ethylene regulation and biological control (Lobo et al. 2018). For example, the inoculation of Pseudomonas fluorescens in a grass species was able to aid in the decomposition of the increased plant $\mathrm{C}$ inputs associated with $\mathrm{eCO}_{2}$, while promoting plant productivity (Nie et al. 2015). In another study, the best performing PGPB under drought stress conditions was selected from field-grown sorghum (Silva et al. 2018). Also, under drought stress conditions, the application of $\mathrm{N}$ fixing bacteria reduced the requirement of chemical fertilizer and enhanced macro and micronutrient concentrations in Medicago scutellata (Shabani et al. 2015). Even in poor soil strata, a mixture of five PGPB was found to have a significant impact on nutrient availability, alongside with the capacity to rehabilitate the soil (Radhapriya et al. 2018). With this strategy, it is possible to perform a pre-selection of the PGPB to optimize plant growth for each specific field condition (Silva et al. 2018). This might be optimal for small farming 
conditions, but in a wider scale, challenges still reside regarding stability and economic feasibility (Lobo et al. 2018).

Another efficient strategy for climate change mitigation is the inclusion of legumes in farming systems, since it allows to naturally reduce the amount of inorganic $\mathrm{N}$ fertilizer, reduce $\mathrm{CO}_{2}$ emissions, amend soil physical properties, maintain soil fertility and decrease pest susceptibility, as recently reviewed by Karkanis et al. (2018). A predictive model that included climate data from the last 80 years demonstrated that the inclusion of a legume in a crop rotation system would decrease $25 \%$ of the greenhouse gas emission (Ma et al. 2018). Besides decreasing denitrification, the inclusion of legumes in intercropping systems has also contributed to improve P-fertilizer-use efficiency and led to increased plant availability of $\mathrm{P}, \mathrm{Fe}$ and $\mathrm{Zn}$ (Xue et al. 2016). Although the use of legumes or legume-residues as cover crops (green manure) might be associated with some disadvantages, such as, lack of persistence or excess $\mathrm{N}$ supply in high vigor crops, they have much lower environmental impact than non-leguminous crops, lower energy demand per unit area and lower global warming potential (Tani et al. 2017). This strategy is key in the modern paradigm of 'sustainable intensification' (Mungai et al. 2016; Pretty et al. 2018), where we find it urgent to shift agriculture practices to be more sustainable and efficient, while also meeting rising human needs.

Amongst the most common promising sustainable agricultural practices, reduced or no-till farming decreases decomposition rates of organic matter and enhances recycling of nutrients, soil structure and water infiltration (Barão et al. 2019). Although this technique was used in ancient agriculture, during Europe's agricultural revolution, tilling was largely adopted, which in the long run, resulted in soils which are eroded, nutritionally poor and deprived of microbial activity (Gomiero 2016; Lal et al. 2007). Lately, the benefits of no-till farming have been discussed in the context of sustainable agriculture, however, due to its fall into disuse, information on the implementation and economics of this strategy is still scarce in certain agricultural areas, which prevents its successful and widespread implementation (Bavorova et al. 2018). Nowadays, technologies for no-till farming are more effective and require less efforts from the farmers (Rafiq et al. 2017). Evidence has shown that these practices also reduce methane emission (Zhao et al. 2016), contribute to the reduction in dissolved-P loss when combined with other land management strategies (Daryanto et al. 2017) and influence the distribution of pesticides between the soil solution and the solid phase (Elias et al. 2018).

While limited research focus has been put on understanding the regulatory mechanisms of differential gene expression under climate change conditions, newest genetic technologies will most certainly impulse sustainable practices in agriculture. However, the limiting conditions to transfer strategies from the research field to crop improvement impair further advances (Kromdijk and Long 2016). Historically, the major focus of plant breeders has been on yield and resistance, but as plants' nutrient content decrease is progressively evident, reversing this problem should also be a priority. Hence, some approaches are under development and are based, for example, on the identification of QTLs for nutrient efficiency under $\mathrm{eCO}_{2}$ and warmer temperatures
Fig. 2 Strategies for mitigation and adaptation to climate changes

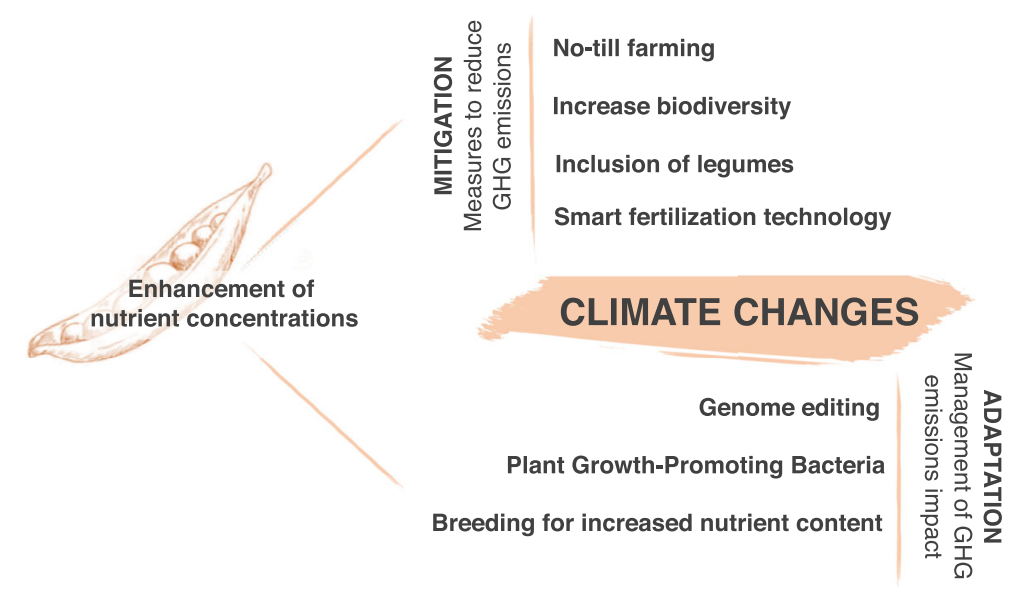


(Pilbeam 2015) or on the study of differentially expressed genes in response to $\mathrm{eCO}_{2}$ (Zhang et al. 2018). With this information, predictive models can be designed and selection for increased food quality can be made (Dwivedi et al. 2018). This can be achieved with the application of gene editing tools (Haque et al. 2018) such as the CRISPR/Cas9 system, which has been successful in developing rice lines with improved seed longevity, high amylase content and resistant starch (Mishra et al. 2018).

\section{Concluding remarks}

Several studies have been conducted in recent decades on the effects of climate change on plant productivity and yield parameters. However, there is a lack of knowledge dedicated to the nutritional dynamics, particularly, on micronutrient-use efficiency under climate changes, which impacts crop nutrient uptake, transport, and remobilization. Rising $\mathrm{CO}_{2}$ has been shown to affect the nutritional value of not only cereals and legume crops, but also fruits and leafy vegetables, but few studies point out that this is not a generalizable phenomenon.

Nowadays, we are facing a compromise between the necessities for higher yields and the prevention of food quality loss. Knowing that nutrient deficiencies are one of the major causes of quality and production losses around the world, understanding the interaction of these stresses with $\mathrm{eCO}_{2}$ is of paramount importance. It seems clear that we can no longer underestimate the effect of $\mathrm{eCO}_{2}$ on food mineral composition and that the likelihood of growing less nutritious food in the future is a real threat both to agriculture and human health.

In this way, a better understanding of the genetic mechanisms, and of the physiological and molecular processes determining mineral nutrient absorption is essential and will help to improve the nutritional performance of grains subject to climate change. In addition, germplasm screening to identify varieties that have a better use of nutrients will provide the tools for biofortification strategies.

Acknowledgements This work was supported by Portuguese National Funds from FCT [grant numbers UID/Multi/50016/ 2019, PTDC/AGRPRO/3972/2014]; and by the European Social Fund through the Northern Operational Program-Norte2020 [NORTE-08-5369-FSE-000007]. We also acknowledge the
European Union's Horizon 2020 research and innovation programme under grant agreement No 731013 for the project 53 of the EPPN2020.

Open Access This article is distributed under the terms of the Creative Commons Attribution 4.0 International License (http:// creativecommons.org/licenses/by/4.0/), which permits unrestricted use, distribution, and reproduction in any medium, provided you give appropriate credit to the original author(s) and the source, provide a link to the Creative Commons license, and indicate if changes were made.

\section{References}

Abadía J, López-Millán AF, Rombolá A, Abadía A (2002) Organic acids and Fe deficiency: a review. Plant Soil 241. https://doi.org/10.1023/a:1016093317898

Abbas S, Sharmila P, Uprety D, Saradhi P (2009) Effects of elevated $\mathrm{CO}_{2}$ on soil physicochemical characteristics under Free Air $\mathrm{CO}_{2}$ Enrichment (FACE) technology. IOP Conference Series: Earth and Environmental Science 6: 292045

Abdelgawad H, Farfan-Vignolo ER, Vos D, Asard H (2015) Elevated $\mathrm{CO} 2$ mitigates drought and temperature-induced oxidative stress differently in grasses and legumes. Plant Sci 231:1-10. https://doi.org/10.1016/j.plantsci.2014.11.001

Ahmed M, Stöckle CO, Nelson R, Higgins S (2017) Assessment of Climate Change and Atmospheric CO2 Impact on Winter Wheat in the Pacific Northwest Using a Multimodel Ensemble. Front Ecol Environ 5. https://doi.org/10.3389 /fevo.2017.00051

Ahuja I, de Vos RC, Bones AM, Hall RD (2010) Plant molecular stress responses face climate change. Trends Plant Sci 15: 664-674. https://doi.org/10.1016/j.tplants.2010.08.002

Ai F, Eisenhauer N, Xie Y, Zhu J, Jousset A, Du W, Yin Y, Zhang X, Ji R, Guo H (2018) Elevated CO2 accelerates polycyclic aromatic hydrocarbon accumulation in a paddy soil grown with rice. PLoS One 13:e0196439. https://doi.org/10.1371 /journal.pone.0196439

Ainsworth EA, Long SP (2005) What have we learned from 15 years of free-air $\mathrm{CO} 2$ enrichment (FACE)? A meta-analytic review of the responses of photosynthesis, canopy properties and plant production to rising CO2. New Phytol 165:351372. https://doi.org/10.1111/j.1469-8137.2004.01224.x

Ainsworth EA, Rogers A, Nelson R, Long SP (2004) Testing the "source-sink" hypothesis of down-regulation of photosynthesis in elevated [CO2] in the field with single gene substitutions in Glycine max. Agric For Meteorol 122:85-94. https://doi.org/10.1016/j.agrformet.2003.09.002

Anandan A, Rajiv G, Eswaran R, Prakash M (2011) Genotypic variation and relationships between quality traits and trace elements in traditional and improved rice (Oryza sativa L.) genotypes. J Food Sci 76:H122-H130. https://doi. org/10.1111/j.1750-3841.2011.02135.x

Arenque BC, Grandis A, Pocius O, de Souza AP, Buckeridge MS (2014) Responses of Senna reticulata, a legume tree from the Amazonian floodplains, to elevated atmospheric $\mathrm{CO} 2$ concentration and waterlogging. Trees 28:1021-1034. https://doi.org/10.1007/s00468-014-1015-0 
Ashraf MA (2012) Waterlogging stress in plants: A review. Afr J Agric Res Vol 7(13). https://doi.org/10.5897/AJARX11.084

Asif M, Yilmaz O, Ozturk L (2017a) Elevated carbon dioxide ameliorates the effect of $\mathrm{Zn}$ deficiency and terminal drought on wheat grain yield but compromises nutritional quality. Plant Soil 411:57-67. https://doi.org/10.1007/s11104-0162996-9

Asif M, Yilmaz O, Ozturk L (2017b) Potassium deficiency impedes elevated carbon dioxide-induced biomass enhancement in well watered or drought-stressed bread wheat. J Plant Nutr Soil Sc 180:474-481. https://doi.org/10.1002 /jpln.201600616

Asif M, Tunc CE, Ozturk L (2018) Changes in yield attributes and $\mathrm{K}$ allocation in wheat as affected by $\mathrm{K}$ deficiency and elevated CO2. Plant Soil 426:153-162. https://doi.org/10.1007 /s11104-018-3603-z

Asif M, Tunc CE, Yazici MA, Tutus Y, Rehman R, Rehman A, Ozturk L (2019) Effect of predicted climate change on growth and yield performance of wheat under varied nitrogen and zinc supply. Plant Soil 434:231-244. https://doi. org/10.1007/s11104-018-3808-1

Barão L, Alaoui A, Ferreira C, Basch G, Schwilch G, Geissen V, Sukkel W, Lemesle J, Garcia-Orenes F, Morugán-Coronado A (2019) Assessment of promising agricultural management practices. Sci Total Environ 649:610-619. https://doi. org/10.1016/j.scitotenv.2018.08.257

Barrett DJ, Richardson AE, Gifford RM (1998) Elevated atmospheric $\mathrm{CO} 2$ concentrations increase wheat root phosphatase activity when growth is limited by phosphorus. Funct Plant Biol 25:87-94. https://doi.org/10.1071/PP97045

Bassu S, Brisson N, Durand JL, Boote K, Lizaso J, Jones JW, Rosenzweig C, Ruane AC, Adam M, Baron C (2014) How do various maize crop models vary in their responses to climate change factors? Glob Chang Biol 20:2301-2320. https://doi.org/10.1111/gcb.12520

Bavorova M, Imamverdiyev N, Ponkina E (2018) Farm-level economics of innovative tillage technologies: the case of no-till in the Altai Krai in Russian Siberia. Environ Sci Pollut R 25:1016-1032. https://doi.org/10.1007/s11356017-9268-y

Beard JL (2008) Why iron deficiency is important in infant development. J Nutr 138:2534-2536. https://doi.org/10.1093 /jn/138.12.2534

Bellaloui N, Hu Y, Mengistu A, Abbas HK, Kassem MA, Tigabu M (2016) Elevated atmospheric carbon dioxide and temperature affect seed composition, mineral nutrition, and $15 \mathrm{~N}$ and 13C dynamics in soybean genotypes under controlled environments. Atlas J Plant Biol: 56-65 https://doi.org/10.5147 /ajpb.2016.0157.

Bencke-Malato M, De Souza AP, Ribeiro-Alves M, Schmitz JF, Buckeridge MS, Alves-Ferreira M (2019) Short-term responses of soybean roots to individual and combinatorial effects of elevated $\left[\mathrm{CO}_{2}\right]$ and water deficit. Plant Sci 280: 283-296. https://doi.org/10.1016/j.plantsci.2018.12.021

Bloom AJ, Smart DR, Nguyen DT, Searles PS (2002) Nitrogen assimilation and growth of wheat under elevated carbon dioxide. P Natl Acad Sc 99:1730-1735. https://doi. org/10.1073/pnas.022627299

Bouis HE, Saltzman A (2017) Improving nutrition through biofortification: A review of evidence from HarvestPlus,
2003 through 2016. Glob Food Sec 12:49-58. https://doi. org/10.1016/j.gfs.2017.01.009

Bowes G (1993) Facing the inevitable: plants and increasing atmospheric $\mathrm{CO}_{2}$. Annu Rev Plant Physiol 44:309-332. https://doi.org/10.1146/annurev.pp.44.060193.001521

Briat J-F, Dubos C, Gaymard F (2015) Iron nutrition, biomass production, and plant product quality. Trends Plant Sci 20: 33-40. https://doi.org/10.1016/j.tplants.2014.07.005

Broadley M, Brown P, Cakmak I, Rengel Z, Zhao F (2012) Function of nutrients: micronutrients. In: Marschner's mineral nutrition of higher plants. Elsevier Ltd, London pp, pp 191-248

Broberg M, Högy P, Pleijel H (2017) CO2-induced changes in wheat grain composition: meta-analysis and response functions. Agron 7:32. https://doi.org/10.3390 /agronomy7020032

Brumbarova T, Matros A, Mock H-P, Bauer P (2008) A proteomic study showing differential regulation of stress, redox regulation and peroxidase proteins by iron supply and the transcription factor FER. Plant J 54:321-334. https://doi.org/10.1111 /j.1365-313X.2008.03421.x

Bunce JA (2008) Contrasting responses of seed yield to elevated carbon dioxide under field conditions within Phaseolus vulgaris. Agric Ecosyst Environ 128:219-224. https://doi. org/10.1016/j.agee.2008.06.003

Bunce JA (2015) Elevated Carbon Dioxide Effects on Reproductive Phenology and Seed Yield among Soybean Cultivars. Crop Sci 55:339-343. https://doi.org/10.2135 /cropsci2014.04.0273

Burgess P, Huang B (2014) Root protein metabolism in association with improved root growth and drought tolerance by elevated carbon dioxide in creeping bentgrass. Field Crop Res 165:80-91. https://doi.org/10.1016/j.fcr.2014.05.003

Burritt DJ (2019) Crop Plant Adaption to Climate Change and Extreme Environments. In: Melton L, Shahidi F, Varelis P (eds) Encyclopedia of Food Chemistry. Academic Press, Oxford, pp 196-201

Cakmak I (2005) The role of potassium in alleviating detrimental effects of abiotic stresses in plants. J Plant Nutr Soil Sc 168: 521-530. https://doi.org/10.1002/jpln.200420485

Cakmak I, Kirkby EA (2008) Role of magnesium in carbon partitioning and alleviating photooxidative damage. Physiol Plant 133:692-704. https://doi.org/10.1111/j.13993054.2007.01042.x

Cakmak I, Kutman UB (2018) Agronomic biofortification of cereals with zinc: a review. Eur J Soil Sci 69:172-180. https://doi.org/10.1111/ejss.12437

Cakmak I, Kalayci M, Kaya Y, Torun A, Aydin N, Wang Y, Arisoy Z, Erdem H, Yazici A, Gokmen O (2010) Biofortification and localization of zinc in wheat grain. J Agric Food Chem 58: 9092-9102. https://doi.org/10.1021/jf101197h

Carvalho SMP, Vasconcelos MW (2013) Producing more with less: Strategies and novel technologies for plant-based food biofortification. Food Res Int 54:961-971. https://doi. org/10.1016/j.foodres.2012.12.021

Chaturvedi AK, Bahuguna RN, Pal M, Shah D, Maurya S, Jagadish KS (2017) Elevated CO2 and heat stress interactions affect grain yield, quality and mineral nutrient composition in rice under field conditions. Field Crop Res 206:149157. https://doi.org/10.1016/j.fcr.2017.02.018 
Chen Z, Wang B, Wang J, Pan G, Xiong Z (2016) Contrasting effects of elevated $\mathrm{CO} 2$ and warming on temperature sensitivity of soil organic matter decomposition in a Chinese paddy field. Environ Monit Assess 188:545. https://doi. org/10.1007/s10661-016-5563-1

Cheng L, Booker FL, Tu C, Burkey KO, Zhou L, Shew HD, Rufty TW, Hu S (2012) Arbuscular Mycorrhizal Fungi Increase Organic Carbon Decomposition Under Elevated CO2. Science 337:1084-1087. https://doi.org/10.1126 /science.1224304

Chrysargyris A, Papakyriakou E, Petropoulos SA, Tzortzakis N (2019) The combined and single effect of salinity and copper stress on growth and quality of Mentha spicata plants. J Hazard Mater 368:584-593. https://doi.org/10.1016/j. jhazmat.2019.01.058

Da Ge T, Sui FG, Sa N, Sun NB, Ha X, Tong CL (2010) Differential responses of yield and selected nutritional compositions to drought stress in summer maize grains. J Plant Nutr 33:1811-1818. https://doi.org/10.1080 /01904167.2010.503829

Daryanto S, Wang L, Jacinthe PA (2017) Meta-analysis of phosphorus loss from no-till soils. J Environ Qual 46:1028-1037. https://doi.org/10.2134/jeq2017.03.0121

Das S, Bhattacharyya P, Adhya T (2011) Impact of elevated CO 2, flooding, and temperature interaction on heterotrophic nitrogen fixation in tropical rice soils. Biol Fertil Soils 47:25-30. https://doi.org/10.1007/s00374-010-0496-2

Dey SK, Chakrabarti B, Prasanna R, Pratap D, Singh SD, Purakayastha TJ, Pathak H (2017) Elevated carbon dioxide level along with phosphorus application and cyanobacterial inoculation enhances nitrogen fixation and uptake in cowpea crop. Arch Agron Soil Sci 63:1927-1937. https://doi. org/10.1080/03650340.2017.1315105

Dietterich LH, Zanobetti A, Kloog I, Huybers P, Leakey ADB, Bloom AJ, Carlisle E, Fernando N, Fitzgerald G, Hasegawa T, Holbrook NM, Nelson RL, Norton R, Ottman MJ, Raboy V, Sakai H, Sartor KA, Schwartz J, Seneweera S, Usui Y, Yoshinaga S, Myers SS (2015) Impacts of elevated atmospheric $\mathrm{CO} 2$ on nutrient content of important food crops. Scientific Data 2:150036. https://doi.org/10.1038 /sdata.2015.36

Dong J-1, Li X, Nazim G, Z-q D (2018a) Interactive effects of elevated carbon dioxide and nitrogen availability on fruit quality of cucumber (Cucumis sativus L.). J Integr Agric 17:2438-2446. https://doi.org/10.1016/S2095-3119(18 $62005-2$

Dong J, Gruda N, Lam SK, Li X, Duan Z (2018b) Effects of Elevated CO2 on Nutritional Quality of Vegetables: A Review. Front Plant Sci 9. https://doi.org/10.3389 /fpls.2018.00924

Dong J, Grylls S, Hunt J, Armstrong R, Delhaize E, Tang C (2018c) Elevated CO2 (free-air CO2 enrichment) increases grain yield of aluminium-resistant but not aluminiumsensitive wheat (Triticum aestivum) grown in an acid soil. Ann Bot-London 123:461-468. https://doi.org/10.1093 /aob/mcy171

Duval BD, Blankinship JC, Dijkstra P, Hungate BA (2012) RETRACTED ARTICLE:CO2 effects on plant nutrient concentration depend on plantfunctional group and available nitrogen: a meta-analysis. Plant Ecol 213:505-521. https://doi.org/10.1007/s11258-011-9998-8
Dwivedi SL, Siddique KH, Farooq M, Thornton PK, Ortiz R (2018) Using Biotechnology-Led Approaches to Uplift Cereal and Food Legume Yields in Dryland Environments. Front Plant Sci 9:1249. https://doi.org/10.3389 /fpls.2018.01249

Elia A, Conversa G (2015) A decision support system (GesCoN) for managing fertigation in open field vegetable crops. Part I-methodological approach and description of the software. Front Plant Sci 6:319. https://doi.org/10.3389 /fpls.2015.00319

Elias D, Wang L, Jacinthe P-A (2018) A meta-analysis of pesticide loss in runoff under conventional tillage and no-till management. Environ Monit Assess 190:79. https://doi.org/10.1007 /s10661-017-6441-1

Ershova A, Popova N, Berdnikova O (2011) Production of reactive oxygen species and antioxidant enzymes of pea and soybean plants under hypoxia and high CO 2 concentration in medium. Russ J Plant Physl 58:982. https://doi. org/10.1134/S1021443711050074

Fanzo J, Davis C, McLaren R, Choufani J (2018) The effect of climate change across food systems: Implications for nutrition outcomes. Glob Food Secur 18:12-19. https://doi. org/10.1016/j.gfs.2018.06.001

FAO (2017) The future of food and agriculture - Trends and challenges. Roeme.

Feng G-Q, Li Y, Cheng Z-M (2014) Plant Molecular and Genomic Responses to Stresses in Projected Future CO2 Environment. Crit Rev Plant Sci 33:238-249. https://doi.org/10.1080 /07352689.2014.870421

Fernando N, Panozzo J, Tausz M, Norton R, Fitzgerald G, Seneweera S (2012a) Rising atmospheric CO2 concentration affects mineral nutrient and protein concentration of wheat grain. Food Chem 133:1307-1311. https://doi.org/10.1016/j. foodchem.2012.01.105

Fernando N, Panozzo J, Tausz M, Norton RM, Fitzgerald GJ, Myers S, Walker C, Stangoulis J, Seneweera S (2012b) Wheat grain quality under increasing atmospheric $\mathrm{CO} 2$ concentrations in a semi-arid cropping system. J Cereal Sci 56: 684-690. https://doi.org/10.1016/j.jcs.2012.07.010

Fernando N, Panozzo J, Tausz M, Norton RM, Fitzgerald GJ, Myers S, Nicolas ME, Seneweera S (2014) Intra-specific variation of wheat grain quality in response to elevated $[\mathrm{CO} 2]$ at two sowing times under rain-fed and irrigation treatments. J Cereal Sci 59:137-144. https://doi.org/10.1016 /j.jcs.2013.12.002

Fischer S, Hilger T, Piepho H-P, Jordan I, Cadisch G (2019) Do we need more drought for better nutrition? The effect of precipitation on nutrient concentration in East African food crops. Sci Total Environ 658:405-415. https://doi.org/10.1016/j. scitotenv.2018.12.181

Godfray HCJ, Beddington JR, Crute IR, Haddad L, Lawrence D, Muir JF, Pretty J, Robinson S, Thomas SM, Toulmin C (2010) Food Security: The Challenge of Feeding 9 Billion People. Science 327:812-818. https://doi.org/10.1126 /science.1185383

Gomiero T (2016) Soil degradation, land scarcity and food security: Reviewing a complex challenge. Sustainability 8:281. https://doi.org/10.3390/su8030281

Gray SB, Brady SM (2016) Plant developmental responses to climate change. Dev Biol 419:64-77. https://doi. org/10.1016/j.ydbio.2016.07.023 
Grover M, Maheswari M, Desai S, Gopinath KA, Venkateswarlu B (2015) Elevated CO2: Plant associated microorganisms and carbon sequestration. Appl Soil Ecol 95:73-85. https://doi.org/10.1016/j.apsoil.2015.05.006

Grusak MA (2001) Plant Macro- and Micronutrient Minerals. eLS In: Encyclopedia of Life Sciences. Nature Publishing Group, London.

Guo J, Zhang M-q, Wang X-w, W-j Z (2015) A possible mechanism of mineral responses to elevated atmospheric $\mathrm{CO} 2$ in rice grains. J Integr Agric 14:50-57. https://doi.org/10.1016 /S2095-3119(14)60846-7

Haase S, Neumann G, Kania A, Kuzyakov Y, Römheld V, Kandeler E (2007) Elevation of atmospheric CO2 and Nnutritional status modify nodulation, nodule-carbon supply, and root exudation of Phaseolus vulgaris L. Soil Biol Biochem 39:2208-2221. https://doi.org/10.1016/j. soilbio.2007.03.014

Haase S, Rothe A, Kania A, Wasaki J, Römheld V, Engels C, Kandeler E, Neumann G (2008) Responses to Iron Limitation in Hordeum vulgare L. as Affected by the Atmospheric CO2 Concentration. J Environ Qual 37:12541262. https://doi.org/10.2134/jeq2006.0136

Haddad LJ, Hawkes C, Achadi E, Ahuja A, Ag Bendech M, Bhatia K, Bhutta Z, Blossner M, Borghi E, Eriksen K (2015) Global Nutrition Report 2015: Actions and accountability to advance nutrition and sustainable development. Intl Food Policy Res Inst.

Hajiboland R (2012) Effect of Micronutrient Deficiencies on Plants Stress Responses. In: Ahmad P, Prasad MNV (eds) Abiotic Stress Responses in Plants: Metabolism, Productivity and Sustainability. Springer New York, New York, NY

Han X, Hao X, Lam SK, Wang H, Li Y, Wheeler T, Ju H, Lin E (2015) Yield and nitrogen accumulation and partitioning in winter wheat under elevated $\mathrm{CO} 2$ : A 3-year free-air $\mathrm{CO} 2$ enrichment experiment. Agric Ecosyst Environ 209:132137. https://doi.org/10.1016/j.agee.2015.04.007

Haque E, Taniguchi H, Hassan MM, Bhowmik P, Karim MR, Śmiech M, Zhao K, Rahman M, Islam T (2018) Application of CRISPR/Cas9 Genome Editing Technology for the Improvement of Crops Cultivated in Tropical Climates: Recent Progress, Prospects, and Challenges. Front Plant Sci 9:617. https://doi.org/10.3389/fpls.2018.00617

Hashiguchi A, Ahsan N, Komatsu S (2010) Proteomics application of crops in the context of climatic changes. Food Res Int 43:1803-1813. https://doi.org/10.1016/j. foodres.2009.07.033

Hatfield JL, Walthall CL (2014) Climate Change: Cropping System Changes and Adaptations. In: Van Alfen NK (ed) Encyclopedia of Agriculture and Food Systems. Academic Press, Oxford

He J, Wang J, He D, Dong J, Wang Y (2011) The design and implementation of an integrated optimal fertilization decision support system. Math Comput Model 54:1167-1174. https://doi.org/10.1016/j.mcm.2010.11.050

Högy P, Fangmeier A (2008) Effects of elevated atmospheric CO2 on grain quality of wheat. J Cereal Sci 48:580-591. https://doi.org/10.1016/j.jcs.2008.01.006

Högy P, Wieser H, Köhler P, Schwadorf K, Breuer J, Franzaring J, Muntifering R, Fangmeier A (2009) Effects of elevated CO2 on grain yield and quality of wheat: results from a 3-year free- air CO2 enrichment experiment. Plant Biol 11:60-69. https://doi.org/10.1111/j.1438-8677.2009.00230.x

Högy P, Brunnbauer M, Koehler P, Schwadorf K, Breuer J, Franzaring J, Zhunusbayeva D, Fangmeier A (2013) Grain quality characteristics of spring wheat (Triticum aestivum) as affected by free-air $\mathrm{CO} 2$ enrichment. Environ Exp Bot 88: 11-18. https://doi.org/10.1016/j.envexpbot.2011.12.007

$\mathrm{Hu}$ Y, Burucs Z, von Tucher S, Schmidhalter U (2007) Short-term effects of drought and salinity on mineral nutrient distribution along growing leaves of maize seedlings. Environ Exp Bot 60:268-275. https://doi. org/10.1016/j.envexpbot.2006.11.003

Hummel M, Hallahan BF, Brychkova G, Ramirez-Villegas J, Guwela V, Chataika B, Curley E, McKeown PC, Morrison L, Talsma EF, Beebe S, Jarvis A, Chirwa R, Spillane C (2018) Reduction in nutritional quality and growing area suitability of common bean under climate change induced drought stress in Africa. Sci Rep 8:16187. https://doi. org/10.1038/s41598-018-33952-4

IPCC (2014) IPCC, 2014: Climate Change 2014: Synthesis Report. Contribution of Working Groups I, II and III to the Fifth Assessment Report of the Intergovernmental Panel on Climate Change.

IPCC (2018) IPCC, 2018: Summary for Policymakers. In: Global warming of $1.5^{\circ} \mathrm{C}$. An IPCC Special Report on the impacts of global warming of $1.5^{\circ} \mathrm{C}$ above pre-industrial levels and related global greenhouse gas emission pathways, in the context of strengthening the global response to the threat of climate change, sustainable development, and efforts to eradicate poverty.

Jablonski LM, Wang X, Curtis PS (2002) Plant reproduction under elevated $\mathrm{CO} 2$ conditions: a meta-analysis of reports on 79 crop and wild species. New Phytol 156:9-26. https://doi. org/10.1046/j.1469-8137.2002.00494.x

Jakobsen I, Smith SE, Smith FA, Watts-Williams SJ, Clausen SS, Grønlund M (2016) Plant growth responses to elevated atmospheric $\mathrm{CO} 2$ are increased by phosphorus sufficiency but not by arbuscular mycorrhizas. J Exp Bot 67:6173-6186. https://doi.org/10.1093/jxb/erw383

Jin CW, Du ST, Chen WW, Li GX, Zhang YS, Zheng SJ (2009) Elevated Carbon Dioxide Improves Plant Iron Nutrition through Enhancing the Iron-Deficiency-Induced Responses under Iron-Limited Conditions in Tomato. Plant Physiol 150: 272-280. https://doi.org/10.1104/pp.109.136721

Jin J, Lauricella D, Armstrong R, Sale P, Tang C (2014) Phosphorus application and elevated $\mathrm{CO} 2$ enhance drought tolerance in field pea grown in a phosphorus-deficient vertisol. Ann Bot-London 116:975-985. https://doi. org/10.1093/aob/mcu209

Jin J, Tang C, Sale P (2015) The impact of elevated carbon dioxide on the phosphorus nutrition of plants: a review. Ann BotLondon 116:987-999. https://doi.org/10.1093/aob/mcv088

Jin J, Armstrong R, Tang C (2019) Impact of elevated CO2 on grain nutrient concentration varies with crops and soils $-\mathrm{A}$ long-term FACE study. Sci Total Environ 651:2641-2647. https://doi.org/10.1016/j.scitotenv.2018.10.170

Kanani H, Dutta B, Klapa MI (2010) Individual vs. combinatorial effect of elevated CO 2 conditions and salinity stress on Arabidopsis thaliana liquid cultures: comparing the early molecuelar response using time-series transcriptomic and 
metabolomic analyses. BMC Syst Biol 4:177. https://doi. org/10.1186/1752-0509-4-177

Kaplan F, Zhao W, Richards JT, Wheeler RM, Guy CL, Levine LH (2012) Transcriptional and metabolic insights into the differential physiological responses of Arabidopsis to optimal and supraoptimal atmospheric CO2. PLoS One 7:e43583. https://doi.org/10.1371/journal.pone.0043583

Karkanis A, Ntatsi GN, Lepse L, Fernández JA, Vågen IM, Rewald B, Alsina I, Kronberga A, Balliu A, Olle M (2018) Faba bean cultivation-Revealing novel managing practices for more sustainable and competitive European cropping systems. Front Plant Sci 9:1115. https://doi.org/10.3389 /fpls.2018.01115

Kazemi S, Eshghizadeh HR, Zahedi M (2018) Responses of Four Rice Varieties to Elevated CO2 and Different Salinity Levels. Rice Sci 25:142-151. https://doi.org/10.1016/j. rsci.2018.04.002

Kimball B, Kobayashi K, Bindi M (2002) Responses of agricultural crops to free-air $\mathrm{CO} 2$ enrichment. Elsevier, ADV AGRON

Kobayashi T, Nishizawa NK (2012) Iron Uptake, Translocation, and Regulation in Higher Plants. Annu Rev Plant Biol 63: 131-152. https://doi.org/10.1146/annurev-arplant-042811105522

Köhler IH, Huber SC, Bernacchi CJ, Baxter IR (2018) Increased temperatures may safeguard the nutritional quality of crops under future elevated $\mathrm{CO} 2$ concentrations. Plant J 97:872886. https://doi.org/10.1111/tpj.14166

Krężel A, Maret W (2016) The biological inorganic chemistry of zinc ions. Arch Biochem Biophys 611:3-19. https://doi. org/10.1016/j.abb.2016.04.010

Kromdijk J, Long SP (2016) One crop breeding cycle from starvation? How engineering crop photosynthesis for rising $\mathrm{CO} 2$ and temperature could be one important route to alleviation. P Roy Soc B-Biol Sci 283:20152578. https://doi.org/10.1098 /rspb.2015.2578

Kumagai E, Aoki N, Masuya Y, Shimono H (2015) Phenotypic Plasticity Conditions the Response of Soybean Seed Yield to Elevated Atmospheric CO2 Concentration. Plant Physiol 169:2021-2029. https://doi.org/10.1104/pp.15.00980

Kumar A, Nayak AK, Das BS, Panigrahi N, Dasgupta P, Mohanty S, Kumar U, Panneerselvam P, Pathak H (2019) Effects of water deficit stress on agronomic and physiological responses of rice and greenhouse gas emission from rice soil under elevated atmospheric CO2. Sci Total Environ 650: 2032-2050. https://doi.org/10.1016/j.scitotenv.2018.09.332

Kumari S, Agrawal M (2014) Growth, yield and quality attributes of a tropical potato variety (Solanum tuberosum L. cv Kufri chandramukhi) under ambient and elevated carbon dioxide and ozone and their interactions. Ecotox Environ Safe 101: 146-156. https://doi.org/10.1016/j.ecoenv.2013.12.021

Lal R, Reicosky D, Hanson J (2007) Evolution of the plow over 10,000 years and the rationale for no-till farming. Soil Tillage Res 93:1-12

Larbi A, Morales F, Abadía A, Abadía J (2010) Changes in iron and organic acid concentrations in xylem sap and apoplastic fluid of iron-deficient Beta vulgaris plants in response to iron resupply. J Plant Physiol 167. https://doi.org/10.1016/j. jplph.2009.09.007

Lawson JR, Fryirs KA, Leishman MR (2017) Interactive effects of waterlogging and atmospheric $\mathrm{CO} 2$ concentration on gas exchange, growth and functional traits of Australian riparian tree seedlings. Ecohydrology 10:e1803. https://doi. org/10.1002/eco.1803

Lenssen GM, van Duin WE, Jak P, Rozema J (1995) The response of Aster tripolium and Puccinellia maritima to atmospheric carbon dioxide enrichment and their interactions with flooding and salinity. Aquat Bot 50:181-192. https://doi. org/10.1016/0304-3770(95)00453-7

Li J, Wu X, Hao S, Wang X, Ling H (2008) Proteomic response to iron deficiency in tomato root. Proteomics 397. https://doi. org/10.1002/pmic.200700942

Li M, Li Y, Zhang W, Li S, Gao Y, Ai X, Zhang D, Liu B, Li Q (2018a) Metabolomics analysis reveals that elevated atmospheric $\mathrm{CO} 2$ alleviates drought stress in cucumber seedling leaves. Anal Biochem 559:71-85. https://doi.org/10.1016/j. ab.2018.08.020

Li Y, Yu Z, Jin J, Zhang Q, Wang G, Liu C, Wu J, Wang C, Liu X (2018b) Impact of Elevated CO2 on Seed Quality of Soybean at the Fresh Edible and Mature Stages. FRONT PLANT SCI 9. https://doi.org/10.3389/fpls.2018.01413

Lobo CB, Tomás MSJ, Viruel E, Ferrero MA, Lucca ME (2018) Development of low-cost formulations of plant growthpromoting bacteria to be used as inoculants in beneficial agricultural technologies. Microbiol Res 219:12-25. https://doi.org/10.1016/j.micres.2018.10.012

Loladze I (2002) Rising atmospheric $\mathrm{CO} 2$ and human nutrition: toward globally imbalanced plant stoichiometry? Trends Ecol Evol 17:457-461. https://doi.org/10.1016/S0169-5347 (02)02587-9

Loladze I (2014) Hidden shift of the ionome of plants exposed to elevated $\mathrm{CO}_{2}$ depletes minerals at the base of human nutrition. Elife 3:e02245-e02245. https://doi.org/10.7554 /eLife. 02245

Long SP, Ainsworth EA, Rogers A, Ort DR (2004) Rising atmospheric carbon dioxide: plants FACE the future. Annu Rev Plant Biol 55:591-628. https://doi.org/10.1146/annurev. arplant.55.031903.141610

López-Millán AF, Morales F, Abadía A, Abadía J (2000) Effects of iron deficiency on the composition of the leaf apoplastic fluid and xylem sap in sugar beet. Implications for iron and carbon transport. Plant Physiol 124. https://doi.org/10.1104 /pp.124.2.873

López-Millán A, Morales F, Gogorcena Y, Abadía A, Abadía J (2009) Metabolic responses in iron deficient tomato plants. J Plant Physiol 166. https://doi.org/10.1016/j. jplph.2008.06.011

Ludewig F, Sonnewald U (2000) High CO2-mediated down-regulation of photosynthetic gene transcripts is caused by accelerated leaf senescence rather than sugar accumulation. FEBS Lett 479:19-24. https://doi.org/10.1016/S0014-5793(00 )01873-1

Ma Z, Flynn J, Libra G, Shi Z (2017) Elevated CO2 Accelerates Depletion of Phosphorus by Common Bean (Phaseolus vulgaris) in association with Altered Leaf Biochemical Properties. Pedosphere. https://doi.org/10.1016/S1002-0160 (17)60420-X

Ma Y, Schwenke G, Sun L, Li Liu D, Wang B, Yang B (2018) Modeling the impact of crop rotation with legume on nitrous oxide emissions from rain-fed agricultural systems in Australia under alternative future climate scenarios. Sci 
Total Environ 630:1544-1552. https://doi.org/10.1016/j. scitotenv.2018.02.322

Madan P, Jagadish S, Craufurd P, Fitzgerald M, Lafarge T, Wheeler T (2012) Effect of elevated CO2 and high temperature on seed-set and grain quality of rice. J Exp Bot 63: 3843-3852. https://doi.org/10.1093/jxb/ers077

Manners R, van Etten J (2018) Are agricultural researchers working on the right crops to enable food and nutrition security under future climates? Glob Environ Chang 53:182-194. https://doi.org/10.1016/j.gloenvcha.2018.09.010

Marschner H (2012) Marschner's Mineral Nutrition of Higher Plants.(Ed.): Marschner, P. Academic press.

McGrath JM, Lobell DB (2013) Reduction of transpiration and altered nutrient allocation contribute to nutrient decline of crops grown in elevated CO2 concentrations. Plant Cell Environ 36:697-705. https://doi.org/10.1111/pce.12007

Medek DE, Schwartz J, Myers SS (2017) Estimated Effects of Future Atmospheric CO2 Concentrations on Protein Intake and the Risk of Protein Deficiency by Country and Region. Environ Health Perspect 125:087002. https://doi.org/10.1289 /ehp41

Mishra R, Joshi RK, Zhao K (2018) Genome editing in rice: Recent advances, challenges, and future implications. Front Plant Sci, 9. https://doi.org/10.3389/fpls.2018.01361

Mitterbauer E, Enders M, Bender J, Erbs M, Habekuß A, Kilian B, Ordon F, Weigel H-J (2017) Growth response of 98 barley (Hordeum vulgare L.) genotypes to elevated $\mathrm{CO} 2$ and identification of related quantitative trait loci using genome-wide association studies. Plant Breed 136:483-497. https://doi. org/10.1111/pbr.12501

Mortensen LM (1994) Effects of elevated CO2 concentrations on growth and yield of eight vegetable species in a cool climate. Sci Hortic 58:177-185. https://doi.org/10.1016/0304-4238 (94)90149-X

Mungai LM, Snapp S, Messina JP, Chikowo R, Smith A, Anders E, Richardson RB, Li G (2016) Smallholder farms and the potential for sustainable intensification. Front Plant Sci 7: 1720. https://doi.org/10.3389/fpls.2016.01720

Murgia I, Arosio P, Tarantino D, Soave C (2012) Biofortification for combating 'hidden hunger' for iron. Trends Plant Sci 17: 47-55. https://doi.org/10.1016/j.tplants.2011.10.003

Myers SS, Zanobetti A, Kloog I, Huybers P, Leakey ADB, Bloom AJ, Carlisle E, Dietterich LH, Fitzgerald G, Hasegawa T, Holbrook NM, Nelson RL, Ottman MJ, Raboy V, Sakai H, Sartor KA, Schwartz J, Seneweera S, Tausz M, Usui Y (2014) Increasing CO2 threatens human nutrition. Nature 510:139-142. https://doi.org/10.1038/nature13179

Myers SS, Wessells KR, Kloog I, Zanobetti A, Schwartz J (2015) Effect of increased concentrations of atmospheric carbon dioxide on the global threat of zinc deficiency: a modelling study. Lancet Glob Health 3:e639-e645

Myers SS, Smith MR, Guth S, Golden CD, Vaitla B, Mueller ND, Dangour AD, Huybers P (2017) Climate Change and Global Food Systems: Potential Impacts on Food Security and Undernutrition. Annu Rev Public Health 38:259-277. https://doi.org/10.1146/annurev-publhealth-031816-044356

Nakandalage N, Seneweera S (2018) Chapter 12 - Micronutrients Use Efficiency of Crop-Plants Under Changing Climate. In: Hossain MA, Kamiya T, Burritt DJ, Phan Tran L-S, Fujiwara $\mathrm{T}$ (eds) Plant Micronutrient Use Efficiency. Academic Press
Nakashima K, Ito Y, Yamaguchi-Shinozaki K (2009) Transcriptional regulatory networks in response to abiotic stresses in Arabidopsis and grasses. Plant Physiol 149:8895. https://doi.org/10.1104/pp.108.129791

Nelson GC, Rosegrant MW, Koo J, Robertson R, Sulser T, Zhu T, Ringler C, Msangi S, Palazzo A, Batka M, Magalhaes M, Valmonte-Santos R, Ewing M, Lee D (2009) Climate Change Impact on Agriculture and Costs of Adaptation. International Food Policy Research Institute, Washington, DC.

Neocleous D, Koukounaras A, Siomos A, Vasilakakis M (2014) Assessing the salinity effects on mineral composition and nutritional quality of green and red "baby" lettuce. J Food Qual 37:1-8. https://doi.org/10.1111/jfq.12066

Newton AC, Johnson SN, Gregory PJ (2011) Implications of climate change for diseases, crop yields and food security. Euphytica 179:3-18. https://doi.org/10.1007/s10681-0110359-4

Nezhadahmadi A, Prodhan ZH, Faruq G (2013) Drought Tolerance in Wheat. Sci World J:1-12. https://doi. org/10.1155/2013/610721

Nie M, Bell C, Wallenstein MD, Pendall E (2015) Increased plant productivity and decreased microbial respiratory $\mathrm{C}$ loss by plant growth-promoting rhizobacteria under elevated $\mathrm{CO} 2$. Sci Rep 5:9212. https://doi.org/10.1038/srep09212

Niu Y, Chai R, Dong H, Wang H, Tang C, Zhang Y (2012) Effect of elevated $\mathrm{CO} 2$ on phosphorus nutrition of phosphatedeficient Arabidopsis thaliana (L.) Heynh under different nitrogen forms. J Exp Bot 64:355-367. https://doi. org/10.1093/jxb/ers341

Norisada M, Motoshige T, Kojima K, Tange T (2006) Effects of phosphate supply and elevated $\mathrm{CO} 2$ on root acid phosphatase activity in Pinus densiflora seedlings. J Plant Nutr Soil Sc 169:274-279. https://doi.org/10.1002/jpln.200520558

Olanrewaju OS, Glick BR, Babalola OO (2017) Mechanisms of action of plant growth promoting bacteria. World J Microbiol Biotechnol 33:197. https://doi.org/10.1007/s11274-0172364-9

O'Mara FP (2012) The role of grasslands in food security and climate change. Ann Bot 110:1263-1270. https://doi. org/10.1093/aob/mes209

Palacios CJ, Grandis A, Carvalho VJ, Salatino A, Buckeridge MS (2019) Isolated and combined effects of elevated CO2 and high temperature on the whole-plant biomass and the chemical composition of soybean seeds. Food Chem 275:610 617. https://doi.org/10.1016/j.foodchem.2018.09.052

Pandey R, Zinta G, AbdElgawad H, Ahmad A, Jain V, Janssens IA (2015) Physiological and molecular alterations in plants exposed to high [CO2] under phosphorus stress. Biotechnol Adv 33:303-316. https://doi.org/10.1016/j. biotechadv.2015.03.011

Pandey P, Ge Y, Stoerger V, Schnable JC (2017) High throughput in vivo analysis of plant leaf chemical properties using hyperspectral imaging. Front Plant Sci 8:1348. https://doi. org/10.3389/fpls.2017.01348

Pang J, Zhu J-G, Xie Z-B, Liu G, Zhang Y-L, Chen G-P, Zeng Q, Cheng L (2006) A new explanation of the $\mathrm{N}$ concentration decrease in tissues of rice (Oryza sativa L.) exposed to elevated atmospheric CO2. Environ Exp Bot 57:98-105. https://doi.org/10.1016/j.envexpbot.2005.04.004

Pang J, Ryan MH, Lambers H, Siddique KH (2018) Phosphorus acquisition and utilisation in crop legumes under global 
change. Curr Opin Plant Biol 45:248-254. https://doi. org/10.1016/j.pbi.2018.05.012

Parajuli R, Thoma G, Matlock MD (2018) Environmental sustainability of fruit and vegetable production supply chains in the face of climate change: A review. Sci Total Environ 650: 2863-2879. https://doi.org/10.1016/j.scitotenv.2018.10.019

Parvin S, Uddin S, Tausz-Posch S, Armstrong R, Fitzgerald G, Tausz M (2019) Grain mineral quality of dryland legumes as affected by elevated $\mathrm{CO} 2$ and drought: a FACE study on lentil (Lens culinaris) and faba bean (Vicia faba). Crop Pasture Science 70:244-253. https://doi.org/10.1071 /CP18421

Pérez-Jiménez M, Hernández-Munuera M, Piñero MC, LópezOrtega G, del Amor FM (2017a) CO2 effects on the waterlogging response of 'Gisela 5' and 'Gisela 6' (Prunus cerasusxPrunus canescens) sweet cherry (Prunus avium) rootstocks. J Plant Physiol 213:178-187. https://doi. org/10.1016/j.jplph.2017.03.011

Pérez-Jiménez M, Hernández-Munuera M, Piñero Zapata MC, López-Ortega G, del Amor FM (2017b) Two minuses can make a plus: waterlogging and elevated $\mathrm{CO} 2$ interactions in sweet cherry (Prunus avium) cultivars. Physiol Plant 161: 257-272. https://doi.org/10.1111/ppl.12590

Pérez-Jiménez M, Piñero MC, del Amor FM (2019) Heat shock, high $\mathrm{CO} 2$ and nitrogen fertilization effects in pepper plants submitted to elevated temperatures. Sci Hortic 244:322-329. https://doi.org/10.1016/j.scienta.2018.09.072

Pérez-López U, Miranda-Apodaca J, Lacuesta M, Mena-Petite A, Muñoz-Rueda A (2015) Growth and nutritional quality improvement in two differently pigmented lettuce cultivars grown under elevated $\mathrm{CO} 2$ and/or salinity. Sci Hortic 195: 56-66. https://doi.org/10.1016/j.scienta.2015.08.034

Petretto GL, Urgeghe PP, Massa D, Melito S (2019) Effect of salinity $(\mathrm{NaCl})$ on plant growth, nutrient content, and glucosinolate hydrolysis products trends in rocket genotypes. Plant Physiol Biochem. https://doi.org/10.1016/j. plaphy.2019.05.012

Petropoulos SA, Levizou E, Ntatsi G, Fernandes Â, Petrotos K, Akoumianakis K, Barros L, Ferreira IC (2017) Salinity effect on nutritional value, chemical composition and bioactive compounds content of Cichorium spinosum L. Food Chem 214:129-136. https://doi.org/10.1016/j. foodchem.2016.07.080

Pilbeam DJ (2015) Breeding crops for improved mineral nutrition under climate change conditions. J Exp Bot 66:3511-3521. https://doi.org/10.1093/jxb/eru539

Poorter H, Van Berkel Y, Baxter R, Den Hertog J, Dijkstra P, Gifford RM, Griffin KL, Roumet C, Roy J, Wong SC (1997) The effect of elevated CO2 on the chemical composition and construction costs of leaves of $27 \mathrm{C} 3$ species. Plant Cell Environ 20:472-482. https://doi.org/10.1046/j.13653040.1997.d01-84.x

Poursarebani N, Nussbaumer T, Simkova H, Safar J, Witsenboer H, van Oeveren J, Dolezel J, Mayer KF, Stein N, Schnurbusch T (2014) Whole-genome profiling and shotgun sequencing delivers an anchored, gene-decorated, physical map assembly of bread wheat chromosome 6A. Plant J 79: 334-347. https://doi.org/10.1111/tpj.12550

Pretty J, Benton TG, Bharucha ZP, Dicks LV, Flora CB, Godfray HCJ, Goulson D, Hartley S, Lampkin N, Morris C, Pierzynski G, Prasad PVV, Reganold J, Rockström J, Smith
P, Thorne P, Wratten S (2018) Global assessment of agricultural system redesign for sustainable intensification. Nat Sustain 1(8):441-446. https://doi.org/10.1038/s41893-0180114-0

Prior J, Connon I, McIntyre E, Adams J, Capon T, Kent J, Rissel C, Thomas L, Thompson S, Westcott H (2018) Built environment interventions for human and planetary health: integrating health in climate change adaption and mitigation. Public Health Res Pract 28(4):e2841831. https://doi. org $/ 10.17061 / \mathrm{phrp} 2841831$

Qiao Y, Miao S, Li Q, Jin J, Luo X, Tang C (2019) Elevated CO2 and temperature increase grain oil concentration but their impacts on grain yield differ between soybean and maize grown in a temperate region. Sci Total Environ 666:405413. https://doi.org/10.1016/j.scitotenv.2019.02.149

Radhapriya P, Ramachandran A, Palani P (2018) Indigenous plant growth-promoting bacteria enhance plant growth, biomass, and nutrient uptake in degraded forest plants. 3 Biotech 8: $154 \mathrm{https} / /$ doi.org/10.1007/s13205-018-1179-1.

Rafiq MH, Ahmad R, Jabbar A, Munir H, Hussain M (2017) Wheat productivity responses in the rice-based system under different no-till techniques and nitrogen sources. Environ Sci Pollut R 24:21797-21806. https://doi.org/10.1007/s11356017-9813-8

Ramzani PMA, Khalid M, Naveed M, Ahmad R, Shahid M (2016) Iron biofortification of wheat grains through integrated use of organic and chemical fertilizers in $\mathrm{pH}$ affected calcareous soil. Plant Physiol Biochem 104:284-293. https://doi. org/10.1016/j.plaphy.2016.04.053

Rasheed R, Iqbal M, Ashraf MA, Hussain I, Shafiq F, Yousaf A, Zaheer A (2018) Glycine betaine counteracts the inhibitory effects of waterlogging on growth, photosynthetic pigments, oxidative defence system, nutrient composition, and fruit quality in tomato. J Hortic Sci Biotechnol 93:385-391. https://doi.org/10.1080/14620316.2017.1373037

Rellán-Álvarez R, Andaluz S, Rodríguez-Celma J, Wohlgemuth G, Zocchi G, Álvarez-Fernández A, Fiehn O, López-Millán AF, Abadía J (2010) Changes in the proteomic and metabolic profiles of Beta vulgaris root tips in response to iron deficiency and resupply. BMC Plant Biol 10:1-15. https://doi. org/10.1186/1471-2229-10-120

Robin A, Vansuyt G, Hinsinger P, Meyer JM, Briat JF, Lemanceau P (2008) Chapter 4 Iron Dynamics in the Rhizosphere: Consequences for Plant Health and Nutrition. Academic Press, ADV AGRON

Rodríguez-Celma J, Lattanzio G, Villarroya D, GutierrezCarbonell E, Ceballos-Laita L, Rencoret J, Gutiérrez A, del Río JC, Grusak MA, Abadía A, Abadía J, López-Millán A-F (2016) Effects of Fe deficiency on the protein profiles and lignin composition of stem tissues from Medicago truncatula in absence or presence of calcium carbonate. J Proteome 140: 1-12. https://doi.org/10.1016/j.jprot.2016.03.017

Rustioni L, Grossi D, Brancadoro L, Failla O (2017) Characterization of iron deficiency symptoms in grapevine (Vitis spp.) leaves by reflectance spectroscopy. Plant Physiol Biochem 118:342-347. https://doi.org/10.1016/j. plaphy.2017.06.031

Sabir A, Sari G (2019) Zinc pulverization alleviates the adverse effect of water deficit on plant growth, yield and nutrient acquisition in grapevines (Vitis vinifera L.). Sci Hortic 244: 61-67. https://doi.org/10.1016/j.scienta.2018.09.035 
Saeed M, Dahab AA, Wangzhen G, Tianzhen Z (2012) A cascade of recently discovered molecular mechanisms involved in abiotic stress tolerance of plants. Omics 16:188-199. https://doi.org/10.1089/omi.2011.0109

Saha S, Chakraborty D, Sehgal VK, Pal M (2015) Potential impact of rising atmospheric $\mathrm{CO} 2$ on quality of grains in chickpea (Cicer arietinum L.). Food Chem 187:431-436. https://doi. org/10.1016/j.foodchem.2015.04.116

Sarker U, Oba S (2018) Response of nutrients, minerals, antioxidant leaf pigments, vitamins, polyphenol, flavonoid and antioxidant activity in selected vegetable amaranth under four soil water content. Food Chem 252:72-83. https://doi. org/10.1016/j.foodchem.2018.01.097

Sarker U, Islam MT, Oba S (2018) Salinity stress accelerates nutrients, dietary fiber, minerals, phytochemicals and antioxidant activity in Amaranthus tricolor leaves. PLoS One 13: e0206388. https://doi.org/10.1371/journal.pone.0206388

Scagel CF, Lee J, Mitchell JN (2019) Salinity from NaCl changes the nutrient and polyphenolic composition of basil leaves. Ind Crop Prod 127:119-128. https://doi.org/10.1016/j. indcrop.2018.10.048

Sgherri C, Pérez-López U, Micaelli F, Miranda-Apodaca J, MenaPetite A, Muñoz-Rueda A, Quartacci MF (2017) Elevated $\mathrm{CO} 2$ and salinity are responsible for phenolics-enrichment in two differently pigmented lettuces. Plant Physiol Biochem 115:269-278. https://doi.org/10.1016/j.plaphy.2017.04.006

Shabani G, Ardakani M, Chaichi M, Friedel J, Khavazi K (2015) Effect of Different Fertilizing Treatments on Nutrient Uptake in Annual Medic (Medicago scutellata cv. Robinson) under Irrigated and Dry Farming Systems. J Agric Sci Technol 17: 299-310

Shahbaz M, Ashraf M (2013) Improving salinity tolerance in cereals. Crit Rev Plant Sci 32:237-249. https://doi. org/10.1080/07352689.2013.758544

Shimono H, Konno T, Sakai H, Sameshima R (2012) Interactive Effects of Elevated Atmospheric $\mathrm{CO} 2$ and Waterlogging on Vegetative Growth of Soybean (Glycine max (L.) Merr.). Plant Prod Sci 15:238-245. https://doi.org/10.1626 /pps.15.238

Sicher RC, Barnaby JY (2012) Impact of carbon dioxide enrichment on the responses of maize leaf transcripts and metabolites to water stress. Physiol Plant 144:238-253. https://doi. org/10.1111/j.1399-3054.2011.01555.x

Silva JF, Silva TR, Escobar IEC, Fraiz ACR, dos Santos JWM, do Nascimento TR, dos Santos JMR, SJW P, de Melo RF, Signor D (2018) Screening of plant growth promotion ability among bacteria isolated from field-grown sorghum under different managements in Brazilian drylands. World $\mathrm{J}$ Microbiol Biotechnol 34:186. https://doi.org/10.1007 /s11274-018-2568-7

Singh SK, Reddy VR (2014) Combined effects of phosphorus nutrition and elevated carbon dioxide concentration on chlorophyll fluorescence, photosynthesis, and nutrient efficiency of cotton. J Plant Nutr Soil SC 177: 892-892-902 https://doi. org/10.1002/jpln.201400117.

Singh SK, Reddy VR (2018) Co-regulation of photosynthetic processes under potassium deficiency across $\mathrm{CO} 2$ levels in soybean: mechanisms of limitations and adaptations. Photosynth Res 137:183-200. https://doi.org/10.1007 /s11120-018-0490-3
Singh SK, Badgujar G, Reddy VR, Fleisher DH, Bunce JA (2013) Carbon dioxide diffusion across stomata and mesophyll and photo-biochemical processes as affected by growth $\mathrm{CO} 2$ and phosphorus nutrition in cotton. J Plant Physiol 170:801-813. https://doi.org/10.1016/j.jplph.2013.01.001

Smethurst CF, Garnett T, Shabala S (2005) Nutritional and chlorophyll fluorescence responses of lucerne (Medicago sativa) to waterlogging and subsequent recovery. Plant Soil 270:3145. https://doi.org/10.1007/s11104-004-1082-x

Steffens D, Hutsch B, Eschholz T, Losak T, Schubert S (2005) Water logging may inhibit plant growth primarily by nutrient deficiency rather than nutrient toxicity. Plant Soil Environ, 10.17221/3630-PSE 51:545

Sublett W, Barickman T, Sams C (2018) Effects of elevated temperature and potassium on biomass and quality of dark red 'Lollo Rosso'lettuce. Hortic 4:11. https://doi.org/10.3390 /horticulturae4020011

Tani E, Abraham E, Chachalis D, Travlos I (2017) Molecular, genetic and agronomic approaches to utilizing pulses as cover crops and green manure into cropping systems. Int $\mathrm{J}$ Mol Sci 18:1202. https://doi.org/10.3390/ijms18061202

Tarekegne A, Bennie A, Labuschagne M (2000) Effects of soil waterlogging on the concentration and uptake of selected nutrients in wheat genotypes differing in tolerance. The eleventh regional wheat workshop for eastern, central and southern Africa, Addis Abeba, Ethiopia, Addis Ababa.

Taub DR, Wang X (2008) Why are Nitrogen Concentrations in Plant Tissues Lower under Elevated CO2? A Critical Examination of the Hypotheses. J Integr Plant Biol 50:1365-1374. https://doi.org/10.1111/j.17447909.2008.00754.x

Thimm O, Essigmann B, Kloska S, Altmann T, Buckhout TJ (2001) Response of Arabidopsis to Iron Deficiency Stress as Revealed by Microarray Analysis. Plant Physiol 127: 1030-1043. https://doi.org/10.1104/pp.010191

Thomas JMG, Boote KJ, Allen LH, Gallo-Meagher M, Davis JM (2003) Elevated Temperature and Carbon Dioxide Effects on Soybean Seed Composition and Transcript Abundance. Crop Sci 43:1548-1557. https://doi.org/10.2135 /cropsci2003.1548

Toreti A, Bassu S, Ceglar A, Zampieri M (2019) Climate Change and Crop Yields. In: Ferranti P, Berry EM, Anderson JR (eds) Encyclopedia of Food Security and Sustainability. Elsevier, Oxford

Vasconcelos M, Clemente T, Grusak M (2014) Evaluation of constitutive iron reductase (AtFRO2) expression on mineral accumulation and distribution in soybean (Glycine max. L). Front Plant Sci 5 https://doi.org/10.3389/fpls.2014.00112.

Vasconcelos MW, Gruissem W, Bhullar NK (2017) Iron biofortification in the 21st century: setting realistic targets, overcoming obstacles, and new strategies for healthy nutrition. Curr Opin Biotechnol 44:8-15. https://doi.org/10.1016 /j.copbio.2016.10.001

Velu G, Guzman C, Mondal S, Autrique JE, Huerta J, Singh RP (2016) Effect of drought and elevated temperature on grain zinc and iron concentrations in CIMMYT spring wheat. J Cereal Sci 69:182-186. https://doi.org/10.1016/j. jcs.2016.03.006

Vicente R, Martínez-Carrasco R, Pérez P, Morcuende R (2018) New insights into the impacts of elevated $\mathrm{CO} 2$, nitrogen, and temperature levels on the regulation of $\mathrm{C}$ and $\mathrm{N}$ metabolism 
in durum wheat using network analysis. New Biotechnol 40: 192-199. https://doi.org/10.1016/j.nbt.2017.08.003

$\mathrm{Vu}$ JC, Allen LHJ (2009) Stem juice production of the C4 sugarcane (Saccharum officinarum) is enhanced by growth at double-ambient CO2 and high temperature. J Plant Physiol 166:1141-1151. https://doi.org/10.1016/j.jplph.2009.01.003

Wang A, Lam SK, Hao X, Li FY, Zong Y, Wang H, Li P (2018a) Elevated $\mathrm{CO} 2$ reduces the adverse effects of drought stress on a high-yielding soybean (Glycine max (L.) Merr.) cultivar by increasing water use efficiency. Plant Physiol Biochem 132: 660-665. https://doi.org/10.1016/j.plaphy.2018.10.016

Wang Y, Hu X, Hou Z, Ning J, Zhang Z (2018b) Discrimination of nitrogen fertilizer levels of tea plant (Camellia sinensis) based on hyperspectral imaging. J Sci Food Agric 98:4659-4664. https://doi.org/10.1002/jsfa.8996

Wasaki J, Yonetani R, Kuroda S, Shinano T, Yazaki J, Fujii F, Shimbo K, Yamamoto K, Sakata K, Sasaki T (2003) Transcriptomic analysis of metabolic changes by phosphorus stress in rice plant roots. PLANT CELL ENVIRON 26: 1515-1523. Transcriptomic analysis of metabolic changes by phosphorus stress in rice plant roots.

Watts-Williams SJ, Andrew Smith F, Jakobsen I (2019) Soil phosphorus availability is a driver of the responses of maize (Zea mays) to elevated $\mathrm{CO} 2$ concentration and arbuscular mycorrhizal colonisation. Symbiosis 77:73-82. https://doi. org/10.1007/s13199-018-0573-0

Wei X, Liu M, Wang S, Jiang M (2018) Seed morphological traits and seed element concentrations of an endangered tree species displayed contrasting responses to waterlogging induced by extreme precipitation. Flora 246-247:19-25. https://doi. org/10.1016/j.flora.2018.07.001

Wesseler J, Zilberman D (2014) The economic power of the Golden Rice opposition. Environ Dev Econ 19:724-742. https://doi.org/10.1017/S1355770X1300065X

Wijewardana C, Reddy KR, Bellaloui N (2019) Soybean seed physiology, quality, and chemical composition under soil moisture stress. FOOD CHEM 278: 92-92-100. https://doi. org/10.1016/j.foodchem.2018.11.035

Wissuwa M, Gamat G, Ismail AM (2005) Is root growth under phosphorus deficiency affected by source or sink limitations? J Exp Bot 56:1943-1950. https://doi.org/10.1093/jxb/eri189

Wu D-X, Wang G-X, Bai Y-F, Liao J-X (2004) Effects of elevated $\mathrm{CO} 2$ concentration on growth, water use, yield and grain quality of wheat under two soil water levels. Agric Ecosyst Environ 104:493-507. https://doi.org/10.1016/j. agee.2004.01.018

Xue Y, Xia H, Christie P, Zhang Z, Li L, Tang C (2016) Crop acquisition of phosphorus, iron and zinc from soil in cereal/ legume intercropping systems: a critical review. Ann BotLondon 117:363-377. https://doi.org/10.1093/aob/mcv182

Yang L, Wang Y, Dong G, Gu H, Huang J, Zhu J, Yang H, Liu G, Han Y (2007) The impact of free-air CO2 enrichment (FACE) and nitrogen supply on grain quality of rice. Field Crop Res 102:128-140. https://doi.org/10.1016/j. fcr.2007.03.006

Yilmaz O, Kahraman K, Ozgur R, Uzilday B, Turkan I, Ozturk L (2017a) Growth performance and antioxidative response in bread and durum wheat plants grown with varied potassium treatments under ambient and elevated carbon dioxide. Environ Exp Bot 137:26-35. https://doi.org/10.1016/j. envexpbot.2017.01.012
Yilmaz O, Kahraman K, Ozturk L (2017b) Elevated carbon dioxide exacerbates adverse effects of $\mathrm{Mg}$ deficiency in durum wheat. Plant Soil 410:41-50. https://doi.org/10.1007/s11104016-2979-x

Yu J, Du H, Xu M, Huang B (2012) Metabolic responses to heat stress under elevated atmospheric $\mathrm{CO} 2$ concentration in a cool-season grass species. J Am Soc Hortic Sci, 10.21273/ JASHS.137.4.221 137:221-228

Yu J, Sun L, Fan N, Yang Z, Huang B (2015) Physiological factors involved in positive effects of elevated carbon dioxide concentration on Bermudagrass tolerance to salinity stress. Environ Exp Bot 115:20-27. https://doi.org/10.1016/j. envexpbot.2015.02.003

Yuhui W, Denghua Y, Junfeng W, Yi D, Xinshan S (2017) Effects of elevated $\mathrm{CO} 2$ and drought on plant physiology, soil carbon and soil enzyme activities. Pedosphere 27:846-855. https://doi.org/10.1016/S1002-0160(17)60458-2

Zaghdoud C, Mota-Cadenas C, Carvajal M, Muries B, Ferchichi A, Martínez-Ballesta MC (2013) Elevated CO2 alleviates negative effects of salinity on broccoli (Brassica oleracea L. var Italica) plants by modulating water balance through aquaporins abundance. Environ Exp Bot 95:15-24. https://doi.org/10.1016/j.envexpbot.2013.07.003

Zaghdoud C, Carvajal M, Ferchichi A, del Carmen M-BM (2016) Water balance and $\mathrm{N}$-metabolism in broccoli (Brassica oleracea L. var. Italica) plants depending on nitrogen source under salt stress and elevated CO2. Sci Total Environ 571: 763-771. https://doi.org/10.1016/j.scitotenv.2016.07.048

Zeng N, Yang Z, Zhang Z, Hu L, Chen L (2019) Comparative Transcriptome Combined with Proteome Analyses Revealed Key Factors Involved in Alfalfa (Medicago sativa) Response to Waterlogging Stress. Int J Mol Sci 20:1359. https://doi. org/10.3390/ijms20061359

Zhang G, Zhang T, Liu J, Zhang J, He C (2018) Comprehensive analysis of differentially expressed genes reveals the molecular response to elevated $\mathrm{CO} 2$ levels in two sea buckthorn cultivars. Gene 660:120-127. https://doi.org/10.1016/j. gene.2018.03.057

Zhao X-z, Wang G-x, Shen Z-x, Zhang H, M-q Q (2006) Impact of elevated CO 2 concentration under three soil water levels on growth of Cinnamomum camphora. J Zhejiang Univ Sci B 7: 283-290

Zhao X, Liu SL, Pu C, Zhang XQ, Xue JF, Zhang R, Wang YQ, Lal R, Zhang HL, Chen F (2016) Methane and nitrous oxide emissions under no-till farming in China: a meta-analysis. Glob Chang Biol 22:1372-1384. https://doi.org/10.1111 /gcb. 13185

Zheng H, Cheng T, Li D, Yao X, Tian Y, Cao W, Zhu Y (2018) Combining Unmanned Aerial Vehicle (UAV)-Based Multispectral Imagery and Ground-Based Hyperspectral Data for Plant Nitrogen Concentration Estimation in Rice. Front Plant Sci 9:936. https://doi.org/10.3389 /fpls.2018.00936

Zhu H, Liu H, Xu Y, Guijun Y (2018a) UAV-based hyperspectral analysis and spectral indices constructing for quantitatively monitoring leaf nitrogen content of winter wheat. Appl Opt 57:7722-7732. https://doi.org/10.1364/AO.57.007722

Zhu X, Song F, Liu S, Liu F, Li X (2018b) Arbuscular mycorrhiza enhances nutrient accumulation in wheat exposed to elevated CO2 and soil salinity. J Plant Nutr Soil Sc 181:836-846. https://doi.org/10.1002/jpln.201700575 
Ziervogel G, Ericksen PJ (2010) Adapting to climate change to sustain food security. Wiley Interdisciplinary Reviews: Climate Change 1: 525-540 https://doi.org/10.1002/wcc.56.

Ziska LH, Bunce JA (2007) Predicting the impact of changing $\mathrm{CO} 2$ on crop yields: some thoughts on food. New Phytol 175:607-618. https://doi.org/10.1111/j.14698137.2007.02180.x

Zocchi G (2006) Metabolic changes in iron stressed dicotiledoneus plants. In: Barton LL, Abadía J (eds) Iron Nutrition in Plants and Rizospheric Microorganisms. Springer, Dordrecht, The Netherlands

Zocchi G, De Nisi P, Dell'Orto M, Espen L, Gallina PM (2007) Iron deficiency differently affects metabolic responses in soybean roots. J Exp Bot 58(5):993-1000. https://doi. org/10.1093/jxb/erl259

Zong Y-Z, Shangguan Z-P (2014) Nitrogen Deficiency Limited the Improvement of Photosynthesis in Maize by Elevated CO2 Under Drought. J Integr Agric 13:73-81. https://doi. org/10.1016/S2095-3119(13)60349-4

Publisher's note Springer Nature remains neutral with regard to jurisdictional claims in published maps and institutional affiliations. 